\title{
A Comparative Legal Analysis of Urban Climate Mitigation and Adaptation in the Building Sector in Brazil, Germany, and South Africa
}

\author{
Oliver Fuo \\ Faculty of Law, North-West University, Potchefstroom, South Africa \\ oliver.fuo@nwu.ac.za \\ Cathrin Zengerling \\ Faculty of Environment and Natural Resources, University of Freiburg, \\ Freiburg, Germany \\ cathrin.zengerling@enrlaw.uni-freiburg.de

\section{Debora Sotto} \\ Institute of Advanced Studies, University of São Paulo, São Paulo, Brazil \\ dsotto@usp.br
}

\begin{abstract}
This article aims to contribute to the growing body of urban climate-governance research from a comparative legal perspective. It analyses the climate-related mitigation and adaptation efforts in the building sector of three cities: Cape Town (South Africa), Hamburg (Germany), and São Paulo (Brazil). We examine national, state, and local laws and policies with a focus on building-related energy, water, and green infrastructure. The comparative analysis reveals similarities and differences in multilevel building-related laws and policies that partly enhance and partly limit cities' climate-mitigation and adaptation efforts. The study also carves out synergies, conflicts, and key challenges in building-related climate mitigation and adaptation at the city level and suggests how identified shortcomings could be overcome.
\end{abstract}

\section{Keywords}

mitigation - adaptation - cities and climate governance - building sector - Cape Town - Hamburg - São Paulo 


\section{Introduction}

Cities have become a prominent actor in global climate governance. Since the beginning of the UNFCCC, local authorities have been represented in deliberations on climate change and have been recognized as important players for various reasons: they are ideally positioned to tailor strategies for climate mitigation and adaptation to suit their local contexts; they play a key role in addressing greenhouse gas emissions related to urbanization; and local authorities are well situated to promote partnerships between a variety of public and private stakeholders. The preamble to the Paris Agreement highlights the importance of all levels of government contributing to climate governance. The 2016 Marrakesh Partnership as well as the Non-State Actor Zone for Climate Action (NAZCA) platform established under the Paris regime aim to incentivize cities to address climate change. ${ }^{1}$ In addition, New Urban Agenda (NUA) and Sustainable Development Goal 11 (SDG 11) politically mandate cities to contribute to efforts on climate mitigation and adaptation.

Climate change makes cities vulnerable, such as through damage to infrastructure from extreme weather events and water scarcity caused by droughts. Cities account for $75 \%$ of global energy consumption ${ }^{2}$ - a share likely to increase because of a growing urban population. ${ }^{3}$ In this context, the building sector is highly relevant for climate mitigation and adaptation. It also represents the sector in which cities enjoy considerable competence. For this reason we focus our study on a comparative analysis of the legal scope for action on, and current practice in, efforts on climate mitigation and adaptation in the building sector ${ }^{4}$ of three cities and their respective national jurisdictions: Cape Town, Hamburg, and São Paulo.

1 NAZCA, 'Cities', 2021, <https://climateaction.unfccc.int/views/stakeholders.html?type=cities >; UNFCCC, 'Marrakesh Partnership for Global Climate Action', 2016, <https://unfccc.int/files/ paris_agreement/application/pdf/marrakech_partnership_for_global_climate_action.pdf>.

2 Mark Swilling et al., City-level Decoupling: Urban Resource Flows and the Governance of Infrastructure Transitions: Working Group on Cities of the International Resource Panel Report (Nairobi: UNEP, 2013), 15.

3 United Nations Department of Economic and Social Affairs, World Urbanization Prospects: The 2018 Revision (ST/ESA/SER.A/420) (New York: UN, 2019), 1.

4 In this article, the term 'building sector' encompasses residential and commercial buildings and the associated energy-related direct and indirect greenhouse gas emissions, as well as buildingrelated climate risks. We use the terms 'building sector' and 'buildings' interchangeably. We take the opportunity in this footnote, which responds to a referee suggestion, to thank the journal's four anonymous referees for their detailed and insightful comments on an earlier version of this article. 
In 2019, global emissions from building construction and operation accounted for the largest share of total final energy consumption (35\%) and energy-related $\mathrm{CO}_{2}$ emissions $(38 \%){ }^{5}$ According to the UN Environmental Programme, residential buildings accounted for $22 \%$ of final energy consumption; non-residential buildings accounted for $8 \%$; and the buildingconstruction industry (the portion of overall industry devoted to manufacturing materials for the construction of buildings, such as cement, glass, and steel) accounted for $5 \%{ }^{6}$

In Brazil, total emissions from all sectors in 2016 stood at 1,305 $\mathrm{Mt} \mathrm{CO}_{2}$ eq. ${ }^{7}$ Between 2000 and 2012, emissions decreased, from 1,911 to 1,047 $\mathrm{Mt} \mathrm{CO}_{2}$ eq. However, from 2012 to 2016 , emissions increased approximately $20 \%$. In the energy sector, in 2016, residential buildings accounted for $24.1 \mathrm{Mt} \mathrm{CO}_{2}$ eq. of

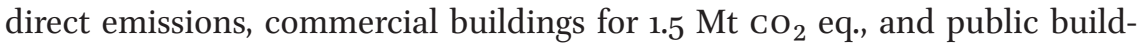
ings for $0.8 \mathrm{Mt} \mathrm{CO}_{2}$ eq. ${ }^{8}$ Emissions of residential buildings increased $2.6 \%$ between 2000 and 2016, whereas emissions of commercial and public buildings decreased $33 \%$ and $62 \%$, respectively, over the same period. ${ }^{9}$

Germany's emissions in 2019 amounted to $810 \mathrm{Mt} \mathrm{CO}_{2}$ eq. ${ }^{10}$ They declined by $14 \%$ since 2010. ${ }^{11}$ Germany's building sector accounted for about $15 \%$ of emissions in 2019. ${ }^{12}$ Building-sector emissions declined by about $18 \%$ between 2010

UNEP, 2020 Global Status Report for Buildings and Construction (Nairobi: UNEP, 2020), 19-20. Such assessments depend on the definitions used, on the reference year chosen, on whether the land sector has been included, and on the quality of the source data, which varies greatly in different parts of the world at different times. As a consequence, it can be quite difficult to compare the emissions of a particular subsector, like for like, across countries. While the focus of our comparison in this article is legal rather than quantitative (see Section 2), we make reference to the best quantitative data on emissions we have been able to find.

6 Ibid., 20.

7 Including land use, land-use change, and forestry (LULUCF), following the GWP-SAR methodology. Without LULuCF the total was 1,o14 $\mathrm{Mt} \mathrm{CO}_{2}$ eq.; see Brazil, 'Fourth Biennial Update Report of Brazil to the United Nations Framework Convention on Climate Change', 2020 (BUR4), <https://unfccc.int/sites/default/files/resource/BUR4.Brazil.pdf>, 46.

8 Ibid., 39 and 46. The BUR4 specifies emissions for residential, commercial, and public buildings as energy 'subsectors'.

9 Ibid., 23 and 39.

10 Excluding LULUCF; see Germany, 'National Inventory Report', 2021, <https://unfccc.int/ documents/273433>, 68. Including LULUCF, emissions were $793 \mathrm{Mt} \mathrm{CO}_{2}$ eq.

11 Excluding LULUCF; ibid.

12 Excluding LULUCF; see Umweltbundesamt (German Environmental Protection Agency), 'Emissionsübersichten in den Sektoren des Bundesklimaschutzgesetzes: Sektorgrafik UBA', 18 August 2021, < www.umweltbundesamt.de/daten/klima/treibhausgas-emissionenin-deutschland\#nationale-und-europaische-klimaziele>. The total amount of emissions 
and 2019 (from 149 to $123 \mathrm{Mt} \mathrm{CO}_{2}$ eq.). ${ }^{13}$ In order to reach the 2030 target for the building sector set by the German Climate Protection Law of 2021, ${ }^{14}$ emissions need to be reduced by further $45 \%$ (from 123 to $67 \mathrm{Mt} \mathrm{CO}_{2}$ eq.). ${ }^{15}$

South Africa's emissions in 2017 were $482 \mathrm{Mt} \mathrm{CO}_{2}$ eq., an increase of $10.4 \%$ since $2000 .{ }^{16}$ Residential buildings accounted for $8 \%$ of total energy consumption while commercial buildings accounted for $14 \% .{ }^{17}$ South Africa's building sector accounted for about $9.3 \%$ of emissions in $2017 .{ }^{18}$ Compared to 2000, building-sector emissions increased about $46 \%$ by 2017: from 26 to $38 \mathrm{Mt} \mathrm{CO}_{2}$ eq. ${ }^{19}$ The South African government aspires to reduce emissions from all sectors in the country in 2030 to $350-440 \mathrm{Mt} \mathrm{CO}_{2}$ eq. ${ }^{20}$ These targets are more ambitious than those of the earlier (2015) NDC: the upper end of the 2025 target has been reduced by $17 \%$, while that of the 2030 target has been reduced by $28 \% .{ }^{21}$ However, no specific mitigation targets have been set for the building sector. This is expected to change when South Africa's Climate Change Bill (2021), which is under parliamentary consideration, becomes law. Section 22 of the Bill envisages that the climate change legislation will establish sectoral emission targets.

$\left(\mathrm{CO}_{2}\right.$ eq.) reported here for 2019 is the same as the data reported pursuant to the UNFCCC in the country's 2021 National Inventory Report (NIR). However, the data from the German Environmental Protection Agency are clustered according to the sectors and related emission-reduction obligations of the 2021 German Climate Protection Law, which specifies the data for the building sector, which is not visible under NIR reporting. Ibid.

Bundes-Klimaschutzgesetz vom 12 Dezember 2019 (BG Bl. I S. 2513), geändert durch Artikel 1 des Gesetzes vom 18 August 2021 (BGBl. I S. 3905) (hereinafter 2021 Federal Climate Protection Law).

Umweltbundesamt, supra note 12, but applying the new target of 67 instead of $70{\mathrm{Mt} \mathrm{CO}_{2}}_{2}$ eq. as stated by the 2021 Federal Climate Protection Law, annex 2.

Including LuluCF. The total excluding LuluCF was $513 \mathrm{Mt} \mathrm{CO}_{2}$ eq.; see South Africa Department of Forestry, Fisheries and the Environment, "The 7th National Greenhouse Gas Inventory Report', 2021, <www.dffe.gov.za/sites/default/files/docs/nir-2017-report.pdf>, 6-7.

See South Africa, Department of Energy, 'The South African Energy Sector Report', 2019, $<$ www.energy.gov.za/files/media/explained/2019-South-African-Energy-Sector-Report.pdf>, 23. South Africa's 7th NIR (supra note 16) does not report on the percentage of total energy consumption for the building sector. Consumption is measured in terajoules (TJ) from 2000 to 2017. See 7 th NIR, 163-4.

Ibid., 162-3.

Ibid.

O South Africa, 'First Nationally Determined Contribution Under the Paris AgreementUpdated September 2021', 2021, <https://www4.unfccc.int/sites/NDCStaging/Pages/All. aspx $>, 15$.

Ibid. 
The design, construction, operation, and refurbishment of buildings can be used to promote energy efficiency and on-site technology for renewable energy, comfort, and resilience to climate change and related disasters. ${ }^{22}$ This means that cities can use their legal competence over buildings to ensure that the above elements speak to the demands of climate change adaptation and mitigation. Depending on the national context, legal competence may include spatial planning; setting of standards for buildings, including building materials; providing infrastructure needed to ensure essential services such as water supply, sewage disposal, storm-water management, energy networks, and green infrastructure; and managing disasters.

We aim to explore from a comparative perspective the efforts on climate change mitigation and adaptation in the building sector of three cities, as embedded in their national jurisdictions. The discussion of the regulatory framework zooms in on how cities use their competences in the building sector to contribute towards climate change mitigation and adaptation. In line with a basic standard in comparative legal studies, we compare the similarities and differences ${ }^{23}$ of climate change governance in the three cities, taking into consideration their different national legal frameworks. We also focus on highlighting synergies, conflicts, and challenges in building-related mitigation and adaptation planning in the three cities. ${ }^{24}$ The comparative method helps to distil the unique natures of the legal systems within which the three cities operate and their commonalities and differences in approach to buildingrelated urban climate governance. We thus seek to elucidate the extent to which the three cities are positioned, in terms of their legal scope of action, to contribute towards achieving the aim of climate change mitigation and adaptation through the building sector.

The paper is structured as follows. We present our methodological approach in Section 2. In Section 3, we compare the scope of competences and available instruments as provided for in the respective national legal frameworks, differentiating between constitutional and legislative provisions. Section 4 presents the relevant state-level legislation for each jurisdiction. The next section goes down to the city level to review the climate change mitigation and adaptation efforts in the building sector in the cities of São Paulo, Hamburg, and Cape Town. Section 6 comprises a comparative analysis of our findings

\footnotetext{
22 UNEP, supra note $5,22$.

23 See John C. Reitz, 'How to Do Comparative Law', 46(1) American Journal of Comparative Law 617 (1998), 620-3. See also Uwe Kischel, Comparative Law (Oxford, UK: Oxford University Press, 2019), 87f.

24 Ibid.
} 
from the international to the local level. Finally, in Section 7 we summarize our key findings and develop several ideas whose implementation would lead to a strengthening of the role of cities in climate mitigation and adaptation efforts related to the building sector.

\section{Methodology}

Global soft law such as NAZCA, SDG 11, and NUA encourages cities globally to contribute to climate mitigation and adaptation irrespective of their legal scope of competence. We have chosen for our comparative legal analysis three cities from three different continents situated in democratic, federal jurisdictions with a comparatively wide scope of local action enshrined in the countries' respective constitutions. All three cities are engaged in climate mitigation and adaptation planning and are amongst the frontrunners in their countries. Data collection was done via desk research and comprises primary sources of law and secondary sources. Key primary sources include constitutions, statutes, ordinances, and case law, as well as legally binding climate mitigation and adaptation plans of the respective cities. Secondary sources encompass legal commentaries, journal articles, grey literature, and non-binding government plans and policies. The comparative legal analysis covers three levels of governance: national, state, and local. It focuses on key legal and policy frameworks, as well as on specific planning instruments for climate mitigation and adaptation in the building sector. We use the term 'building sector' to encompass residential and commercial buildings and the associated energy-related direct and indirect greenhouse gas emissions, as well as building-related climate risks. In order to structure our analysis, we focus on three building-related sub-sectors: regulation of energy demand and provision of energy; water; and green infrastructure. In terms of energy, the analysis scrutinizes the production, consumption, and distribution of energy related to buildings and the associated emissions. With regard to water, we encompass building-related drinking-water demand and supply as well as wastewater management. In the area of green infrastructure, we concentrate on urban drainage, green spaces, and stormwater management. Due to the need to limit the length of the analysis, further building-related subsectors such as solid-waste treatment and associated emissions are excluded.

To our knowledge this is the first study that focuses on cities' climate mitigation and adaptation efforts in the building sector from a comparative legal 
perspective. ${ }^{25}$ In a previous study we analysed the role of cities in international climate change mitigation law and transnational climate governance, again using the cities of Cape Town, São Paulo, and Hamburg as case studies. ${ }^{26}$ Another study has looked at how integrated technological, nature-based, and social solutions have been used by cities in South Africa, Germany, and Singapore to adapt to climate change. ${ }^{27}$ In addition, there are case studies focusing on the three jurisdictions of Brazil, Germany, and South Africa with a pure internal and non-comparative approach. ${ }^{28}$ While a comparative casestudy approach is rather common in the literature on climate governance

25 For a comparative study on the role of law in urban climate governance in London and Los Angeles and the respective national legal frameworks, see Heike Schroeder and Harriet Bulkeley, 'Global Cities and the Governance of Climate Change: What Is the Role of Law in Cities?', 36 (2) Fordham Urban Law Journal 313 (2009).

26 Cathrin Zengerling, Debora Sotto, and Oliver Fuo, 'Cities and Climate Change Mitigation Law from a Polycentric and Comparative Perspective', in Research Handbook on Climate Change Mitigation Law, edited by Leonie Reins et al. (Cheltenham: Edward Edgar, forthcoming 2022).

27 Brenda B. Lin et al., 'Integrating Solutions to Adapt Cities for Climate Change', 5(7) Viewpoint e479 (2021).

28 For Brazil, see Gabriela Marques Di Giulio et al., 'Bridging the Gap Between Will and Action on Climate Change Adaptation in Large Cities in Brazil', 19 Regional Environmental Change 2491 (2019); and Rafael D'Almeida Martins and Leila da Costa Ferreira, 'Climate Change Action at the City Level: Tales from Two Megacities in Brazil', 22(3) Management of Environmental Quality 344 (2011). For Germany, see Antje Otto, Kristine Kern, Wolfgang Haupt, Peter Eckersley, and Annegret H. Thieken, 'Ranking Local Climate Policy: Assessing the Mitigation and Adaptation Activities of 104 German Cities', 167(1) Climatic Change 1 (2021); Julius Hagelstange, Cornelia Rösler, and Katharina Runge, Klimaschutz, Erneuerbare Energien und Klimaanpassung in Kommunen: Maßnahmen, Erfolge, Hemmnisse und Entwicklungen: Ergebnisse der Umfrage 2020 (Berlin: Deutsches Institut für Urbanistik, 2021); Stephan Mitschang (ed.), Klimaschutz und Klimaanpassung in der Regionalund Bauleitplanung: Fach- und Rechtsfragen, vol. 40 Nomos (2021); Michael Sauthoff, 'Raumordnung und Bauplanung', in Handbuch Klimaschutzrecht, edited by Michael Rodi (Munich: Beck, 2022, forthcoming); Cathrin Zengerling, 'Kommunale Klimaschutzplanung', in Handbuch Klimaschutzrecht, edited by Michael Rodi (Munich: Beck, 2022); Friederike Behr and Jan-Hendrik Kamlage, 'Kommunaler Klimaschutz: Handlungsmöglichkeiten und Rahmenbedingungen in deutschen Städten und Gemeinden', KWI-Working Paper, 2/2015, Essen: Kulturwissenschaftliches Institut Essen (KWI), <https://nbn-resolving.org/ urn:nbn:de:o168-ssoar-68793-2>; Kristin Barbey, Metropolregion im Klimawandel-Räumliche Strategien Klimaschutz und Klimaanpassung, Zur Entwicklung gesamträumlicher Konzepte am Beispiel der Metropolregion Rhein-Neckar (Karlsruhe: KIT Scientific Publishing, 2014). For a Europe-wide study, see Diana Reckien et al., 'How are Cities Planning to Respond to Climate Change? Assessment of Local Climate Plans from 885 Cities in the EU-28', 191 Journal of Cleaner Production 207 (2018). For South Africa, see Pierre Mukheibir and Gina Ziervogel, 'Developing a Municipal Adaptation Plan (MAP) for Climate Change: The City of Cape Town', 19(1) Environment and Urbanisation 143 (2007); Darryl Colenbrander, Anton 
and planning, ${ }^{29}$ studies in law usually focus on the national or supra-national level. ${ }^{30}$ Due to the rising relevance of meaningful local contributions to solve globally and locally intertwined environmental challenges, we wish to complement studies on urban governance and planning with a legal analysis, while at the same time adding a local perspective to broader-scale legal research. By scrutinizing how higher levels of law in a country shape the local, city-level, scope for action we also contribute to research on multilevel climate governance. Our comparative analysis benefits from the fact that the three authors acquired their legal qualifications in the selected jurisdictions and are therefore well positioned to undertake a comparative legal study of this nature.

Although there is no generally accepted definition of a city from an interdisciplinary perspective due to a diverse range of factors, for the purposes of this article we understand a city to be a legally recognized municipal government exercising administrative, executive, and legislative powers within a clearly defined geographic boundary. In adopting this definition, we are aware of the diverse features and spatial dimensions of cities, but wish to concentrate on their governing authority as local public authorities recognized in legislation or in a constitution. Part of the complexity of what a city entails is underlined by our three case studies: Cape Town is one of eight metropolitan municipalities designated as such in South Africa's Constitution and in national legislation. The administrative boundary of the city encircles its entire metropolitan area. The City of Hamburg has the dual status of a municipality and a federal state of Germany. It is enveloped by the Metropolitan Region of Hamburg which is about three times the size of the City of Hamburg but has no legal identity of its own under German law. The City of São Paulo only captures a part of the Metropolitan Region of São Paulo, the latter having its own separate constitutional and legislative status.

\section{3}

\section{National Legal Frameworks}

The legal scope for action in planning for urban climate mitigation and adaptation is significantly shaped by the national jurisdiction. Here, we introduce

Cartwright, and Anna Taylor, 'Drawing a Line in the Sand: Managing Coastal Risks in the City of Cape Town', 91(1) South African Geographical Journal 1 (2015).

29 JoAnn Carmin, Isabelle Anguelovski, and Debra Roberts, 'Urban Climate Adaptation in the Global South: Planning in an Emerging Policy Domain', 32(1) Journal of Planning Education and Research 18 (2012).

30 Andreas Fleig, Nicole M. Schmidt, and Jale Tosun, 'Legislative Dynamics of Mitigation and Adaptation Framework Policies in the EU', 3(1) European Policy Analysis 101 (2017). 
key elements of constitutional law and national legislation in Brazil, Germany, and South Africa that both enable and limit municipal action in the building sector.

\subsection{Constitutions}

The discussion that follows shows that constitutions in all three jurisdictions confer a significant scope of competence on municipalities to address climate mitigation and adaptation in the building sector.

\subsubsection{Brazil's Constitution}

Brazil is a federation of three levels, consisting of the Federal Union at the national level, 26 states at the regional or state level, and 5,570 municipalities at the local level. In addition to the 26 states, Brazil also has a Federal District, where its capital, Brasília, is located. The Federal District enjoys both state and municipal competences. Cities are under the jurisdiction of municipalities. According to the Constitution (1988), all federative entities are given legislative and executive attributions in the form of either exclusive or shared competences. As holders of political, administrative, executive, and fiscal autonomy, municipalities can adopt local laws, set up and manage their own administration, collect local taxes, and manage their own budget. ${ }^{31}$

Brazil's municipalities have the power to act on environmental protection at the local level (Article 23.vI) — including climate change mitigation and adaptation $^{32}$ - and to supplement national and state environmental laws in accordance with their local interests (Article 30.II). Urban planning is essentially

31 Luciana Leite Lima et al., 'Planejamento Governamental nos Municípios Brasileiros: Em Direção a Uma Agenda de Pesquisa', 18(2) Cadernos EBAPE.BR 323 (2O2O).

32 Some legal scholars argue that Brazil's municipalities have an enforceable duty to act on climate change, based on Article 225 of the Constitution, which states that it is incumbent upon the Public Authority to ensure the effectiveness of the public right to an ecologically balanced environment. See, for instance, Vinícius Lameira Bernardo, 'Mudanças climáticas: Estratégias de litigância e o papel do Judiciário no combate as causas e efeitos do aquecimento global no contexto brasileiro', 4(6) Revista Jurídica do Ministério Público do Estado do Paraná 283 (2017). However, considering the constitutional distribution of powers, municipal competences to legislate and to act on environmental protection are largely dependent on the guidelines set by national and state laws. In particular, the 2009 National Policy on Climate Change does not obligate municipalities to adopt their own climate change laws, policies, or plans (for more detail, see Section 3.2.1, below.). Therefore, even though Brazilian municipalities certainly have powers to act on climate change, it is questionable whether exercising these powers is an enforceable duty. On the other hand, climate litigation is in its early stages in Brazil; changes in constitutional intepretation by the courts could lead to the recognition of climate action as an enforceable duty imposed on all federative entities in Brazil, including municipalities. 
a local or municipal issue. According to Article 182(1) of the Constitution, municipalities with 20,00o inhabitants or more are obliged to produce Master Plans to set core territorial planning guidelines, and coordinate land use, environmental protection, and sectoral policies and regulations at the local level. ${ }^{33}$ They have exclusive competence to approve zoning laws, land-use regulations, and building codes (Article 3o.vIII), following the general urban policy guidelines established by national law, such as the 2001 Statute of the City. Other key sectoral competences such as on housing, mobility, sanitation, and waste management, are shared among all federative entities (Article 23.IX). This means that cities can take action in these areas subject to guidelines established by national laws.

According to Article 25(3) of the Constitution, States have the power to create metropolitan regions through legislation. Metropolitan regions are made up of conurbated municipalities. They are established with the aim to better facilitate the provision of public functions that are of common interest within their boundaries, such as functions relating to housing, transportation, and sanitation. According to the 2015 Statute of the Metropolis, ${ }^{34}$ a metropolitan region must be governed by an administrative body consisting of representatives of the state and the participating municipalities, acting pursuant to the guidelines, principles, and tools established by a Metropolitan Plan, approved in the form of a state law. ${ }^{35}$

Currently there are 74 metropolitan regions in the country. None of them has fully implemented the governing system introduced by the 2015 Statute of the Metropolis. The reasons are that a national law, adopted in 2018, has displaced the deadlines and sanctions originally imposed for compliance with the Statute; and the Federal Union has frozen national funding for metropoli$\tan$ development. It is nonetheless noteworthy that, in 2019, the Metropolitan Region of Campinas, an industrial regional centre in the State of São Paulo, was the first in the country to launch a Metropolitan Emissions Inventory, with the aim of coordinating the mitigation measures of participating municipalities. ${ }^{36}$

33 Nir Mualam and Debora Sotto, 'From Progressive Property to Progressive Cities: Can Socially Sustainable Interpretations of Property Contribute Toward Just and Inclusive City-Planning? Global Lessons', 12(11) Sustainability 1 (2020).

34 Brazil, 'Lei n. 13.089, de 12 de janeiro de 2015 - Institui o Estatuto da Metrópole, altera a Lei $\mathrm{n}^{\circ}$ 10.257, de 10 de julho de 2001, e dá outras providências', 2015, <www.planalto.gov.br/ ccivil_03/_ato2015-2018/2015/lei/l1308g.htm> (2015 Statute of the Metropolis).

35 Lúcia Camargos Melchiors and César Wagner, 'The Brazilian Metropolitan Regions in the Context of the Statute of Metropolis: The Importance of Collaborative Governance', 5(1) Metropolitan-Przeglad Naukowy 8 (2016).

36 Prefeitura de Campinas, 'Mudança do Clima', 2019, <www.campinas.sp.gov.br/governo/meioambiente/mudanca-do-clima.php> (Municipality of Campinas, 'Climate Change', 2019). 
Energy production and distribution in Brazil are essentially a matter of national competence. ${ }^{37}$ According to the Constitution (Articles 22.IV and 21.XII-b), the Federal Union has exclusive powers to legislate on energy production and distribution, and to develop electric energy services and installations. The states, on the other hand, are exclusively competent to develop piped natural gas services (Article 25(2)). According to the 2021 National Energy Report, the residential sector and the services sector in Brazil are responsible for $10.8 \%$ and $4.7 \%$ of the country's final energy consumption, respectively. ${ }^{38}$ In the residential sector, $46.4 \%$ of energy consumption is electricity, whereas liquified petroleum gas, firewood, and natural gas, used for water heating and cooking, respectively make up $24.4 \%, 26.1 \%$, and $1.6 \%$ of the sector's total energy consumption. ${ }^{39}$

Regulation of water resources is highly complex in Brazil. In accordance with Articles 26.I and 20.III of the Constitution, rivers are state assets, except for those flowing through more than one state, which are considered national assets. The Federal Union has exclusive powers to legislate on water issues (Article 22.IV), to institute the national water-resources management system, and to define criteria for water-use grants (Article 21.XIX). On the other hand, all federative entities are equally competent to control and inspect water concessions in their respective territory (Article 23.XI). Municipalities oversee all sanitation services, namely urban drainage, water distribution, sewage collection, and waste management (Article 3o.v), except if they are part of a metropolitan region, in which case the metropolitan entity can assume the provision of those services within metropolitan borders. Lastly, in terms of disaster management, the Federal Union is exclusively competent to legislate on civil defence (Article 22.XXVIII) and to plan and promote permanent defence against public calamities, in particular droughts and floods (Article 21.XVIII). However, an argument could be made that states and municipalities also have a power to act on disaster management, as a competence derived from the

37 Lira Luz Benites Lazaro, at al., 'Energy Transition in Brazil: Is There a Role for Multilevel Governance in a Centralized Energy Regime?', 85 Energy Research and Social Science 102404 (2022).

38 Ministério de Minas e Energia and Empresa de Pesquisa Energética, 'Balanço Nacional de Energia: 77', 2021, <www.epe.gov.br/sites-pt/publicacoes-dados-abertos/publicacoes/ PublicacoesArquivos/publicacao-6o1/topico-588/Relatório Síntese BEN 2021-ab 202O_ v2.pdf>, 25 .

39 Ibid., 35 . 
constitutional duty to protect and preserve the environment (Article 225) and to guarantee the quality of life in cities (Article 182).40

\subsubsection{Germany's Constitution}

Germany's federal system has two levels: the federal union (Bund) and 16 federal states (Länder), including three city-states (Berlin, Bremen, and Hamburg). Municipalities are regional authorities within their respective states. There are about 10,800 municipalities in Germany; just 14 of them have more than 500,000 inhabitants. ${ }^{41}$ Article 28(2) of the German Constitution (Grundgesetz) empowers municipalities to regulate and manage local affairs. ${ }^{42}$ This so-called right to local self-government (Recht der kommunalen Selbstverwaltung) comprises legislative as well as administrative functions. For example, German municipalities may issue municipal ordinances and raise and spend local taxes. Apart from local self-government, municipalities fulfil state functions in certain areas according to constitutional, federal, and state law. ${ }^{43}$

The right to local self-government allows municipalities a considerable scope of action in climate mitigation and adaptation. However, it is limited to 'local affairs', which typically encompass activities such as the administration of municipal companies, management of local traffic, water and energy supply, nutritional safety, housing supply, local police, fire protection, education, and health. ${ }^{44}$ There must be a genuine local link going beyond mere political interest. ${ }^{45}$ This is not a limiting factor with regard to climate adaptation, since adaptive measures against climate effects such as heat islands, heavy rainfall, and storm surges have genuinely local effects. With regard to climate mitigation, however, there has been some debate over whether municipalities may take action within their scope of local competence in the field of land-use planning mainly aimed at alleviating a global and not a genuinely local problem. Court rulings and the 2011 Climate Amendment to the Federal Building Code have affirmed that mitigation measures do fall within the competence. ${ }^{46}$ Land-use

40 See, for example, Henrique Rosmaninho Alves, 'A Proteção das Gerações Futuras em Face dos Desastres Naturais nas Constituições Contemporâneas' (The Protection of Future Generations in the Face of Natural Disasters in Contemporary Institutions), 25(46) Direito em Debate 164 (2016).

41 J. Rudnika, 'Anzahl der Gemeinden in Deutschland nach Gemeindegrößenklassen', $3^{1}$ December 2020, Statista, <https://de.statista.com/statistik/daten/studie/1254/umfrage/ anzahl-der-gemeinden-in-deutschland-nach-gemeindegroessenklassen/>. Johannes Hellermann, in BeckOK GG (commentary on the German Constitution), edited by Volker Epping and Christian Hillgruber, 49th edition, 15 November 2021, GG Art. 28, 20-58.

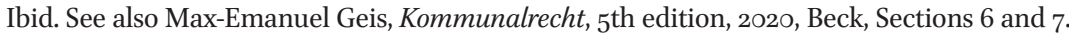
See, for example, list in Article 83 of the Constitution of the Free State of Bavaria, 1946.

45 Geis, supra note 43, Section 6.

46 Sauthoff, supra note 28,29 . 
planning is therefore a major legal basis for municipalities to use to mitigate (and adapt to) climate change. ${ }^{47}$ Many German municipalities have adopted integrated or distinct climate mitigation and adaptation plans to strategically steer their activities. ${ }^{48}$

The German Constitution grants shared legislative competences to the national and state level in all main areas related to climate mitigation and adaptation in the building sector. This shared or concurrent legislative competence can take two forms. In all areas listed in Article 74(1) of the Constitution, the federal level may enact laws that overrule state legislation and prevent the states from (further) legislating in the field. These areas encompass land law, regional law, nature- and landscape-protection law, and water law. Since a reform of the Constitution in 2006, Article 72(3) regulates a so-called 'deviation legislation competence' in favour of the states for a subset of these areas, including regional law, nature- and landscape-protection law, and water law. In these areas the state may enact legislation even if it deviates from the federal regulation. In case of conflicting legislation, the later legislative act prevails.

\subsubsection{South Africa's Constitution}

South Africa is a federal state constituted of national, provincial, and local levels (or 'spheres') of government. The local level consists of 257 municipalities of three different categories-metropolitan, district, and local. ${ }^{49}$ In the pre-democratic era, municipalities were creatures of statute with very limited powers and only a service-delivery mandate; however, the 1996 Constitution brought about significant local-government reform. The entire Chapter 7 of the Constitution is dedicated to local government; it covers areas such as the mandate, status, powers, and functions of municipalities.

The Constitution provides a broad developmental mandate for municipalities. They must, among other things, promote a safe and healthy environment; provide services to communities in a sustainable manner; participate in national and provincial development programmes; and contribute towards

47 Ibid.

48 For a recent analysis see Otto et al., supra note $28,1-23$.

49 In terms of section 155 of the Constitution, a municipality is either metropolitan (Category A), local (Category B), or district (Category C). A metropolitan municipality has exclusive municipal legislative and executive authority in its area. A local municipality shares municipal legislative and executive authority with a district municipality within whose area it falls. A district municipality has executive and legislative authority in an area that includes more than one municipality; see Section $155(1)(a)-(c)$ of the Constitution. See also Sections ${ }^{1-3}$ of the Local Government (Municipal Structures) Act 1998. The City of Cape Town is a metropolitan municipality. 
realizing the rights in the Bill of Rights, including the right to an environment that is not harmful to human health or well-being. ${ }^{50}$ Pursuant to Section 24 of the Constitution, municipalities are mandated to adopt and implement reasonable legislative and other measures to prevent pollution and ecological degradation, promote conservation, and secure ecologically sustainable development and use of natural resources. This broad mandate implies a constitutional duty to respond to climate change.

Municipalities enjoy self-governing powers. Pursuant to Section 151(3) of the Constitution, a municipality has the right to govern the local-government affairs of its community subject to national and provincial legislation and in compliance with the Constitution. A municipality must structure and manage its administration, budgeting, and planning processes to give priority to the basic needs of its community (Section 153). Municipalities have powers to generate the revenue needed to deliver on their mandate by imposing rates on property and surcharges on fees for services provided (Section 229(1-2)). Property rates and service charges for water and electricity consumption are their main sources of revenue. Thus, municipalities face the difficult task of limiting electricity and water consumption in response to the problem of climate change while selling those services to generate revenue. The majority of municipalities cannot generate sufficient revenue, and intergovernmental fiscal transfers are inadequate to meet the fiscal shortfalls of most cities. ${ }^{51}$

Section 156 of the Constitution gives municipalities the executive and legislative powers needed to effectively administer all the matters listed in Schedule $4 \mathrm{~B}$ and $5 \mathrm{~B}$ of the Constitution. These Schedules entail that municipalities have powers over a wide range of areas, which include building regulations, electricity distribution and gas reticulation, municipal airports, spatial planning, municipal health services, municipal public transport, air and noise pollution, rain-and-storm-water management systems in built-up areas, the provision of potable water and sanitation services, management of systems used to supply potable water and domestic waste-water (grey water), sewage disposal systems, municipal parks and recreation, municipal roads, solid-waste disposal, and street lighting. Municipalities are solely responsible for making spatial-planning decisions in their jurisdictions. ${ }^{52}$ This is important to the building

50 This flows from a joint reading of Sections $7(2), 8(1), 24$, and 152-3 of the Constitution.

51 Oliver Fuo, 'Funding and Good Financial Governance as Imperatives for Cities' Pursuit of SDG 11', in The Globalisation of Urban Governance, edited by Helmut Aust and Anel du Plessis (New York: Routledge, 2019), 100-3.

$5^{2}$ Minister of Local Government, Environmental Affairs and Development Planning, Western Cape v. Habitat Council and Others 2014 (4) SA 437 (CC), para. 19. 
sector, as a municipality can use these powers to regulate how and where new building development may occur. However, pursuant to Schedule $4 \mathrm{~B}$ of the Constitution, the powers of municipalities in the energy sector are limited to the distribution and sale of electricity. The generation of electricity is done at the national level through a state-owned entity, ESкOM, which generates and supplies about $95 \%$ of electricity. Es KOM's power plants are mostly coal-fired, and in 2019 emitted about $213 \mathrm{Mt} \mathrm{CO}_{2}$ eq. Coal-fired electricity generation is the dominant source of emissions in South Africa. ${ }^{53}$ Es KOM's energy-generation mandate limits how cities can contribute to mitigating emissions from this sector. At the UNFCCC's COP 26 in 2021, South Africa secured US\$8.5 billion in finance, over five years, from Britain, France, Germany, the United States, and the European Union, to support the installation of new clean-energy infrastructure, speed up the shift away from coal, and provide assistance to workers who are affected by the shift. ${ }^{54}$ If this plan is successfully executed, it will change ESKOM's heavy reliance on coal in the near future.

The matters listed in Schedules $4 \mathrm{~B}$ and $5^{\mathrm{B}}$ of the Constitution are considered 'original' local-government powers and functions because they cannot be taken away from the competence of municipalities without an amendment of the Constitution. ${ }^{55}$ National and provincial governments may regulate how municipalities exercise their original powers and functions (Section 155(7)); however, e.g. regulation is limited to setting broad guidelines within which municipalities must operate, e.g. regulation setting out uniform minimum standards. ${ }^{56}$ Any more intrusive attempt at regulating local government's original powers will likely be declared unconstitutional.

The division of powers and functions between municipalities and other spheres of government in terms of Schedules 4 and 5 of the Constitution is not always clear. ${ }^{57}$ For example, in City of Johannesburg Metropolitan Municipalityv.

53 EcoMetrix Africa, ESKOM Carbon Footprint 2019 (Rosebank: EcoMetirx Africa, 2020), 18.

54 Brad Plumer, 'South Africa secured $\$ 8.5$ billion to transition away from coal', 2021, <www. nytimes.com/2021/11/o3/world/africa/south-africa-coal-renewables.html>.

55 A stringent procedure must be followed for such an amendment; see Oliver Fuo, 'The Courts and Local Governments in South Africa', Federalism and the Courts in Africa: Design and Impact in Comparative Perspectives, edited by Yonatan Fessha and Karl Kossler (London: Routledge, 2020), 105-6.

56 Oliver Fuo, 'Intrusion Into the Autonomy of South African Local Government: Advancing the Minority Judgment in the Merafong City Case', 5o(2) De Jure 324 (2017), 329-30.

57 For a detailed discussion, see Anel du Plessis and Oliver Fuo, 'Governing Authorities in the Same Boat and a Tale of Two Schedules: Marius Nel v Hessequa Local Municipality (2015)', 20 Commonwealth Journal on Local Governance 71-8o (2017); Oliver Fuo, 'Role of Courts in Interpreting Local Government's Environmental Powers in South Africa', 18 Commonwealth Journal on Local Governance 17-35 (2015). 
Blue Moonlight Properties 39 (Pty) Ltd and Another, ${ }^{58}$ the City of Johannesburg refused to provide temporary accommodation to a group of people in severe need evicted from private property, on the ground that housing is not a municipal function because it is listed in the Schedules of the Constitution as an area of competence for national and provincial governments. The City argued that its obligation to provide emergency housing pursuant to the right of access to adequate housing (Section 26 of the Constitution) was limited to those evicted from public buildings. ${ }^{59}$ The Constitutional Court rejected the argument, holding the City's emergency-housing policy to be unconstitutional to the extent that it excluded people in severe need of housing evicted from private property. The Court held that Section 26 of the Constitution as well as housing legislation impose an obligation on all three spheres of government to contribute toward realizing the right to housing. ${ }^{60}$ It also held that the City, besides its entitlement to approach the province for assistance, has both the power and the duty to finance its own emergency-housing scheme. ${ }^{61}$ This case is but one example of a blurring of functions among the three spheres of government, which can lead to inaction on a municipality's part. The case also illustrates that the socio-economic rights obligations imposed on local government by Chapter 2 of the Constitution (the Bill of Rights) are a source of executive and legislative power for municipalities.

The blurring of powers and functions is also manifested in the area of water. Pursuant to Schedule $4 \mathrm{~B}$ of the Constitution, municipalities are responsible for providing drinking water, management of rain-water run-off in built-up areas, greywater, and the systems for providing potable water. However, it is not clear from the Constitution who is responsible for managing South Africa's water resources, such as freshwater sources. This is partly attributed to the fact that, unlike other functional areas such as 'housing', 'environment', and 'agriculture', 'water' is not listed as a functional area in Schedules $4 \mathrm{~A}$ and $5 \mathrm{~A}$ of the Constitution. ${ }^{62}$ This notwithstanding, Section 3 of the National Water Act 1998 makes the national Minister of Water and Sanitation ultimately responsible

$5^{8} 2012(2)$ BCLR 15 O (CC).

59 Section 26 of the Constitution provides that: '(1) Everyone has the right to have access to adequate housing. (2) The state must take reasonable legislative and other measures, within its available resources, to achieve the progressive realisation of this right. (3) No one may be evicted from their home, or have their home demolished, without an order of court made after considering all the relevant circumstances. No legislation may permit arbitrary evictions.'

6o City of Johannesburg v. Blue Moonlight, supra note 58, paras 24, 42-67.

61 Ibid., para. 67.

62 See Du Plessis and Fuo, supra note $57,71-8$ o. 
for managing South Africa's water resources. This includes the bulk supply of water from dams and rivers. ${ }^{63}$ The lack of clarity on whether municipalities may take part in managing water resources was addressed in Marius Nel $v$. Hessequa Local Municipality. ${ }^{64}$ Hessequa Local Municipality and Swellendam Municipality had adopted by-laws relating to the management and use of rivers within their jurisdictional areas. ${ }^{65}$ Certain sections of the by-laws were directed at regulating various boating activities and required that boats using the rivers should be licensed by the municipalities. The applicants, who were owners of holiday homes in the area, argued that the by-laws were unconstitutional because municipalities have no power to regulate the use of rivers. ${ }^{66}$ The court held that it is entirely permissible for a municipality to adopt by-laws making it compulsory for people wishing to use boats on rivers or to fish in rivers in its area of jurisdiction be licensed, and to authorize officers to enforce such by-laws. ${ }^{67}$ The High Court reasoned that a purposive reading of certain provisions of the Constitution gives municipalities the power to regulate the use and management of rivers within their areas of jurisdiction. ${ }^{68}$ The result was taken to confirm that municipalities can take action to assist the national government to manage water resources in South Africa. In view of the threats posed by climate change, such as increased droughts, municipalities may be empowered to implement additional measures to manage the sustainable use of, for example, ground-water resources. The discussion of the City of Cape Town, in Section 5, below, shows that the City used this power to manage water scarcity during the droughts of 2017-2019.

Section 156(4) of the Constitution obliges national and provincial governments to assign to a municipality, by agreement, any matter listed in Schedule $4 \mathrm{~A}$ and $5 \mathrm{~A}$ if the matter would most effectively be administered locally and if the municipality has the capacity to deliver the function. Matters listed in Schedule 4A are concurrent areas of national and provincial legislative competence, while Schedule $5 \mathrm{~A}$ lists functional areas of exclusive provincial legislative competence. Assignment therefore constitutes an additional source of powers and functions for well-performing municipalities. In addition, a municipality also has the right to exercise any power concerning a matter reasonably necessary for, or incidental to, the effective performance of its functions

\footnotetext{
63 Fuo, supra note $56,331$.

64 Marius Nel and Others v. Hessequa Local Municipality and Others (2015) Case No. 12576/2013 (14 December 2015).

65 Ibid., para. 5 .

66 Ibid., paras 2-3 and 9.

67 Ibid., paras 13 and 16.

68 Ibid., paras 11-13.
} 
(Section 156(5) of the Constitution). This incidental power is wide and suggests that municipalities have considerable leeway in taking the action necessary to realize their mandate, including that of responding to climate change. In City of Cape Town v. Robertson, the Constitutional Court described the current powers of local government:

The Constitution has moved away from a hierarchical division of governmental power and has ushered in a new vision of government in which the sphere of local government is interdependent, 'inviolable and possesses the constitutional latitude within which to define and express its unique character' subject to constraints permissible under our Constitution. A municipality under the Constitution is not a mere creature of statute otherwise moribund save if imbued with power by provincial or national legislation. A municipality enjoys 'original' and constitutionally entrenched powers, functions, rights and duties that may be qualified or constrained by law and only to the extent the Constitution permits. Now the conduct of a municipality is not always invalid only for the reason that no legislation authorises it. Its power may derive from the Constitution or from legislation of a competent authority or from its own laws. ${ }^{69}$

The above excerpt confirms that the power of municipalities is wide and suggests that a municipality can use its initiative to take action, to the extent that this relates to the building sector, in order to address challenges related to climate change. With will and resources, municipalities can implement a variety of measures on climate change mitigation and adaptation in the building sector. However, as already seen above, in some instances, the blurred scope of concurrent powers and functions in the Constitution negatively affects this potential. ${ }^{70}$

The comparative overview above shows that the constitutions of the federal states of Brazil, Germany, and South Africa establish municipalities as local governmental units with legislative, executive, and administrative powers that can be exercised over a broad field of competences that speak to the building sector in general. Under all constitutions, municipalities may use their powers and areas of competence to implement climate change mitigation and adaptation measures in the building sector. Whereas this engagement is voluntary

69 City of Cape Town and Another v. Robertson and Another 2005 (2) SA 323 (CC), para. 6 o.

70 See Featherbrooke Homeowners Association NPC v. Mogale City Local Municipality and Others (High Court: Gauteng Local Division, Johannesburg) (unreported), case number 11292/2020 (25 January 2021). 
or not specifically mandated in Germany and Brazil, in South Africa there is a constitutional duty on municipalities to mitigate and adapt to climate change, although it is significantly limited in important areas. Municipalities in all three countries have fiscal powers and are generally subject to regulation by national and state governments.

\subsection{National Legislation}

National legislation and its related policies expand on the powers, functions, and tools that municipalities can use to contribute towards climate change mitigation and adaptation in the building sector. Here we give a concise overview of the key instruments in the three countries that empower municipalities in this regard.

\subsubsection{Brazilian Legislation}

Brazil gave effect to its National Policy on Climate Change in 2009 through a national law. ${ }^{71}$ The National Policy provides principles, goals, guidelines, and tools, and expressly acknowledges the role of municipalities in tackling climate change. ${ }^{72}$ As a central guideline, the National Policy encourages and supports the participation of federal, state, and municipal governments, as well as the industrial sector, academia, and civil society, in the development and execution of policies, plans, programs, and actions related to climate change. The 2009 legislation does not oblige municipalities to adopt local climate plans. Most local governments in fact lack both the resources and the technical capacity to do so, and they heavily depend on the financial and technical support of the Federal Union and the states. Apart from a few projects supported by the National Climate Fund (Fundo Clima), ${ }^{73}$ managed by the Brazilian National Development Bank (BNDES), there is no permanent funding for local climate action in Brazil. As a result, very few municipalities-larger cities and state capitals for the most part-have developed emission inventories or climate policies and plans. They have usually done so with the support of NGOs and international networks such as ICLEI and C40.74

71 Brazil, 'Lei n. 12.187, de 29 de dezembro de 2009. Institui a Política Nacional sobre Mudança do Clima: PNMC e dá outras providências', 2009, <www.planalto.gov.br/ccivil_03/_ato20072010/2009/lei/l12187.htm> (hereinafter 2009 National Policy on Climate Change).

72 Debora Sotto, et al., 'Aligning Urban Policy with Climate Action in the Global South: Are Brazilian Cities Considering Climate Emergency in Local Planning Practice?', 12(18) Energies 1 (2019).

73 CEPAL, IPEA, and GIZ, Avaliação do Fundo Clima (Santiago: CEPAL, 2016).

74 Laura Silvia Valente de Macedo and Pedro Roberto Jacobi, 'Subnational Politics of the Urban Age: Evidence from Brazil on Integrating Global Climate Goals in the Municipal Agenda', 5(1) Palgrave Communications 1 (2019). 
Regarding mitigation for the building sector, the National Policy sets only broad recommendations on the efficient use of energy and water and on the establishment of sustainability indicators, mitigation standards, and goals. As national emissions are relatively low in the energy sector compared with the agriculture and land-use sectors ${ }^{75}$ the national legislation does not set up any emission-pricing or taxation schemes. Therefore, mitigation in the energy sector is strongly reliant on the exploitation of renewable-energy sources and on incentives for efficient energy consumption. A Technical Group for Energy Efficiency in Buildings was created in 2003 to regulate energy-efficiency assessment in the building sector, within the framework of the National Policy for Conservation and Efficient Use of Energy (2001). ${ }^{76}$ The Technical Group has established a labelling system to classify buildings according to energyefficiency levels. The system currently operates on a voluntary basis, but is due to become mandatory at some point in the future.

In terms of adaptation and disaster-risk reduction, the National Adaptation Plan $(2016)^{77}$ recommends certain strategic actions related to the building sector, such as affordable housing projects for vulnerable populations, energyefficiency standards, clean-construction technologies, and the implementation of sustainable drainage works and projects, especially those aimed at reducing floods.

Building codes, as well as the provision of basic urban infrastructure, including green spaces, storm-water management, and urban drainage, are entirely within the legal scope of action of municipalities, following urban development guidelines provided by national laws, such as the Statute of the City (2001), ${ }^{78}$ the National Sanitation Policy (2007), ${ }^{79}$ and the National Policy

75 Brazil, Ministério da Ciência, Tecnologia, Inovações e Comunicações; Secretaria de Políticas para a Formação e Ações Estratégicas; Coordenação Geral do Clima, 'Clima Estimativas Anuais de Emissões de Gases de Efeito Estufa No Brasil', 2019, <www.mctic. gov.br/mctic/opencms/ciencia/SEPED/clima/Comunicacao_Nacional/Estimativas_Anuais. html?searchRef=gases do efeito estufa\&tipoBusc $>$.

76 Brazil, 'Lei n. 10.295, de 17 de outubro de 2001. Dispõe Sobre a Política Nacional de Conservação e Uso Racional de Energia e dá Outras Providências', 2001, <www.planalto.gov. br/ccivil_03/leis/leis_2001/l10295.htm> (hereinafter 2001 National Policy for Conservation and Rational Use of Energy).

77 Brazil, 'Plano Nacional de Adaptação à Mudança do Clima (PNA). Instituído Pela Portaria MMA ${ }^{\circ}$ 150, de 10 de maio de 2016', 2016, <https://antigo.mma.gov.br/clima/adaptacao/ plano-nacional-de-adaptacao.html $>$ (hereinafter 2016 National Adaptation Plan).

78 Brazil, 'Lei n. 10.257, de 10 de julho de 2001. Regulamenta os Arts. 182 e 183 da Constituição Federal, estabelece diretrizes gerais da política urbana e dá outras providências', 2001, <www. planalto.gov.br/ccivil_03/leis/leis_2001/ho257.htm> (hereinafter 2001 Statute of the City).

79 Brazil, 'Lei n. 11.445, de 5 de janeiro de 2007. Estabelece as diretrizes nacionais para o saneamento básico e dá outras providências', 2007, <www.planalto.gov.br/ccivil_03/_ ato2007-2010/2007/lei/l11445.htm> (hereinafter 2007 National Sanitation Policy). 
on Water Resources (1997). ${ }^{80}$ The Statute of the City provides municipalities with a toolbox aimed at generating financial resources or collecting vacant land for urban interventions. ${ }^{81}$ In terms of financing, municipalities can generate financial resources by selling development rights to the private sector. ${ }^{82}$ In terms of land, municipalities can acquire vacant plots through the transfer of development rights, ${ }^{83}$ pre-emption rights, ${ }^{84}$ and eminent domain. ${ }^{85}$

Regarding sustainable construction methods, the Statute of the City encourages the use of operating systems, construction standards, and technology inputs aimed at reducing environmental impacts and saving natural resources, ${ }^{86}$ especially in urban-renewal projects. ${ }^{87}$ The Statute of the City also recommends a planned territorial distribution of population and economic activities to avoid and correct urban-growth distortions as well as urban pollution, environmental degradation, and exposure to disasters. ${ }^{88}$

According to the Statute of the City, the 959 municipalities included in the National Disaster Risk Register, by Cemaden (Centro Nacional de Monitoramento e Alertas de Desatres Naturais: National Disaster Monitoring and Warning Center), ${ }^{89}$ must map all their risk areas and also include in their respective Master Plans provisions on disaster prevention and population relocation, as well as guidelines for the regularization of informal settlements, urban drainage, and the management of public green areas. ${ }^{90}$

Disaster management is more specifically regulated by the National Policy on Protection and Civil Defence (2012), ${ }^{91}$ which creates a multilevel governance

8 o Brazil, 'Lei n. 9.433, de 8 de janeiro de 1997. Institui a Política Nacional de Recursos Hídricos e dá outras providências', 1997, <www.planalto.gov.br/ccivil_o3/leis/l9433.htm> (hereinafter 1997 National Policy on Water Resources).

81 Debora Sotto, 'Terra e Recursos Financeiros Para a Habitação Social: A Cota de Solidariedade no Plano Diretor de 2014 em São Paulo' (Land and Financial Resources for Social Housing: The Solidarity Quota in São Paulo's 2014 Master Plan), 8(3) Revista de Direito da Cidade 842 (2016).

$82 \quad 2001$ Statute of the City, supra note 78 , arts $28-31$.

83 Ibid., art. 35 .

84 Ibid., arts 25 to 27.

85 Ibid., art. 4.V, a.

86 Ibid., art. 2.XVII.

87 Ibid., art. 32, para. 2.III.

88 Ibid., art. 2.VI.

89 Cemaden, 'Municípios monitorados', date unknown <http://www2.cemaden.gov.br/ municipios-monitorados-2/> (Monitored municipalities).

90 Supra note 82 , art. 42-A.

91 Brazil, 'Lei n, 12.6o8, de 10 de abril de 2012. Institui a Política Nacional de Proteção e Defesa Civil e dá outras providências', 2012, <www.planalto.gov.br/ccivil_03/_ato2011-2014/2012/lei/ l126o8.htm> (hereinafter 2012 National Policy on Protection and Civil Defence). 
framework ${ }^{92}$ for disaster prevention, emergency response, and disaster mitigation, with the participation of national, state, and local governments. Within this framework, all municipalities must conduct a survey of risk areas, ${ }^{93}$ and approve Contingency Plans, ${ }^{94}$ with provisions on immediate response to, and mitigation of, disasters, as well as Disaster Risk Reduction Plans, ${ }^{95}$ in accordance with the national ${ }^{96}$ and state ${ }^{97}$ Protection and Civil Defence Plans.

As a natural resource, water is regulated pursuant to a multilevel governance scheme ${ }^{98}$ set up by the National Policy on Water Resources (1997). ${ }^{99}$ Each water basin is governed by a Water Basin Council, following a specific management plan. ${ }^{100}$ The rights to exploit water as an economic resource are regulated by a National Water Agency ${ }^{101}$ and are granted to private or public concessionaires by the Federal Union ${ }^{102}$ with the participation of the relevant states. $^{103}$

On the other hand, water distribution, sewage collection, and stormwater management are sanitation services, regulated by the National Sanitation Policy (2007), extensively revised in 2020.104 It provides general guidelines, principles, goals, and tools for all sanitation services, ${ }^{105}$ which must be rendered by municipalities, directly or through public concessions, according to local or regional sanitation plans. ${ }^{106}$ In metropolitan regions, sanitation

See also Katia Atsumi Nakayama and Marcio Siqueira Machado, 'Appropriation of Disaster Risk Reduction in Brazil: Relations Between Civil Defense and Urban Planning as a Social Process Leading to Sustainability', in Integrating Social Responsibility and Sustainable Development: Addressing Challenges and Creating Opportunities, edited by Walter Leal Filho, Ubiratã Tortato, and Fernanca Frankenberger (Cham: Springer, 2021), 3-18.

98 See also Lilian Bechara Elabras Veiga and Alessandra Magrini, 'The Brazilian Water Resources Management Policy: Fifteen Years of Success and Challenges', 27 Water Resources Management 2287 (2013). 1997 National Policy on Water Resources, supra note 8o.

100 Ibid., ch. III, arts 37-8.

101 Ibid., ch.IV, art. 44.

102 Ibid., ch. VI, art. 29.II.

103 Ibid., ch. VI, art. 3o.I.

1042007 National Sanitation Policy, supra note 79.

105 Ibid., arts 1-3 and 22.

106 Ibid., art. 8.I. 
services must be rendered by the corresponding metropolitan entity, with the participation of relevant municipalities and the state. ${ }^{107}$

\subsubsection{German Legislation}

Germany's Federal Climate Protection Law (2019) follows a sectoral regulatory approach. It was declared partly unconstitutional by the country's Constitutional Court because it lacked a detailed plan for emission reductions after 2030. ${ }^{108}$ In response, the legislature adopted a revised Climate Protection Law in July $2021 .^{109}$ It provides that Germany is to reach climate neutrality by 2045 , as well as interim targets for emission reductions of $65 \%$ by 2030 and $88 \%$ by 2040 over 1990 levels. The emission budget is split among the sectors of industry, energy, buildings, transport, agriculture, waste, etc., and is linked to annual emission-reduction targets up until 2030. ${ }^{110}$ For building-related emissions, the targets for the energy and building sectors are especially relevant. The energy sector has a target to reduce emissions from $280 \mathrm{Mt} \mathrm{CO}_{2}$ eq. in 2020 to $108 \mathrm{Mt} \mathrm{CO}_{2}$ eq. in 203 . The building sector is to reduce emissions from 123 $\mathrm{Mt} \mathrm{CO}_{2}$ eq. in 2019 to $67 \mathrm{Mt} \mathrm{CO}_{2}$ eq. in 2030.111

Due to constitutional provisions that prohibit the national legislature (Bund) from referring new duties to the municipal level, ${ }^{112}$ the Federal Climate Protection Law neither defines any emission reduction targets for municipalities nor requires them to produce climate-action plans or local emission inventories. ${ }^{113}$ States (Länder), however, may do so, but only if they simultaneously provide municipalities with finance to pay for the new tasks. Some of the state climate-protection laws explicitly address the municipal level. ${ }^{114}$ The only relevant link directly from the national to the municipal level is Section 13 of the

107 Ibid., art. 8.II.

108 BVerfG, Beschluss des Ersten Senats vom 24 März 2021, 1 BvR 2656/18, Rn. 1-270.

109 Bundes-Klimaschutzgesetz vom 12 Dezember 2019 (BG Bl. I S. 2513), geändert durch Artikel 1 des Gesetzes vom 18 August 2021 (в B Bl. I S. 3905) (2021 Federal Climate Protection Law of 12 December 2019, Federal Law Gazette I p. 2513).

110 Ibid., annex 2 of the 2021 Federal Climate Protection Law.

111 Ibid.

112 So-called Durchgriffsverbot, included in Art. 84 I 7 and Art. 85 I 2 in the German Basic Law (Grundgesetz) with the 2006 federalism reform.

113 There is an emerging discourse on whether a change in constitutional law should enable the national legislature to regulate municipal climate mitigation and adaptation efforts; Michael Rodi, 'Begriff und Charakteristika des Klimaschutzrechts', in Handbuch Klimaschutzrecht, edited by Michael Rodi (Munich: Beck, 2021); Cathrin Zengerling, 'Kommunale Klimaschutzplanung', in Handbuch Klimaschutzrecht, edited by Michael Rodi (Munich: Beck, 2022).

114 See Zengerling et al., supra note 26; Cathrin Zengerling, 'Städte im polyzentrischen Klimaschutzregime', 1 Zeitschrift für Umweltrecht 3 (2020). 
Federal Climate Protection Law, which obliges all public authorities, including municipalities, to 'consider' the purpose and targets of that law in their planning and decision-making (Berücksichtigungsgebot). ${ }^{115}$

The key national steering instrument of municipal climate mitigation efforts is the funding program National Climate Protection Initiative (Nationale Klimaschutzinitiative, or NKI). ${ }^{116}$ It funds municipal climate action in two key sub-programs: the Municipal Guideline (Kommunalrichtlinie) and the Masterplan Guideline (Masterplan-Richtlinie). Between 2008 and the end of 2020, funds from the National Climate Protection Initiative supported more than 35,900 projects. ${ }^{117} \mathrm{~N} \mathrm{KI}$ states that funding of $€ 1.2$ billion from the Initiative triggered additional investments of $€_{4}$ billion. ${ }^{118}$ Supported measures included initial consulting on municipal climate protection, the development of climateprotection plans, and the appointment of climate-protection managers. The participation of municipalities in the Municipal Guideline funding program does not require them to pursue ambitious climate-protection goals. Only the Masterplan Guideline, which is significantly smaller in total funding, requires that participating municipalities aim to reduce their greenhouse gas emissions by $95 \%$ by 2050 (over 1990 levels) and to reduce final energy consumption by $50 \%$ in the same period. Only 38 cities, counties, and regional associations received funding through this more ambitious program during the 2016-2020 funding period. ${ }^{119}$

Neither the Federal Climate Protection Law nor the national funding program address climate adaptation. During the legislative revision process, the Federal Council proposed inclusion of a section on climate adaptation, but this was rejected by the Federal Parliament as not fitting with the structure of a mitigation-focused act. ${ }^{120}$ The national framework for climate adaptation is the Climate Adaptation Strategy (2008). ${ }^{121}$

Zengerling, 'Städte', supra note 114, with further references. With regard to the 'requirement to consider' in the Climate Protection Law in general, see Martin Kment, 'Klimaschutzziele und Jahresemissionsmengen: Kernelemente des Neuen Bundes-Klimaschutzgesetzes', 21 Neue Zeitschrift für Verwaltungsrecht 1537 (2020), $1543 f$.

116 N KI, 'Zahlen und Fakten', 2021, < www.klimaschutz.de/zahlen-und-fakten>.

117 Ibid.

118 Ibid.

119 Among the larger German cities in this programme are Frankfurt am Main, Stuttgart, Hannover, Münster, Braunschweig, Kiel, Magdeburg, Mainz, Rostock, Potsdam, Heidelberg, Osnabrück, and Göttingen.

120 Deutscher Bundestag, 'Drucksache 19/3023o', 2 June 2021, <https://dserver.bundestag.de/ btd/19/302/193023o.pdf>, 37, annex 4 .

121 Bundesministerium für Umwelt, Naturschutz und Nukleare Sicherheit, Deutsche Anpassungsstrategie, 23 October 2020, <www.bmu.de/themen/klima-energie/ 
The key regulatory tool for reaching the energy sector's emissionreduction targets is the EU ETS and its German implementation (Treibhausgasemissionshandelsgesetz).122 The most relevant legislation for emission reduction in the building sector is the 2020 Building Energy Law (Gebäudeenergiegesetz) $)^{123}$ and the 2019 Fuel Emissions Trading Act (Brennstoffemissionshandelsgesetz). ${ }^{124}$ The former aims at improving energy efficiency in buildings and at enhancing renewable energy for heating, cooling, and electricity. It sets energy-efficiency standards as well as requirements for the use of renewable energy for new and existing buildings. The Fuel Emissions Trading Act, revised in 2020, expands the German emission-trading scheme to the building and transport sectors. Accordingly, emissions from heating fuels such as oil and gas used in buildings need to be covered by certificates, thus pricing emissions that are not so far encompassed by the EU ETS.

German municipalities have a large influence on the building sector due to their constitutionally enshrined planning autonomy and related competences in the field of land-use planning. The Federal Building Code $(\mathrm{FBC})^{125}$ is the regulatory framework for land-use planning and defines its key legal instruments. Since a reform in 2011, Section 1(5) of the FBC states that land-use plans are to contribute to climate change mitigation and adaptation. For example, they may require the construction of renewable-energy-compatible buildings, compulsory connection to a heating grid that includes a high share of renewable heat, the provision of charging infrastructure for e-mobility, green roofs, decentralized water-management systems, and water-retention areas (Section 9 of the F BC). However, there is evidence that municipalities do not yet effectively

klimaschutz/anpassung-an-den-klimawandel/> (Federal Ministry for the Environment, Nature Conservation and Nuclear Safety, German Adaptation Strategy).

Treibhausgas-Emissionshandelsgesetz vom 21 Juli 2011 (BG Bl. I S. 1475), das zuletzt geändert durch Artikel 18 des Gesetzes vom 10 August 2021 (BG Bl. I S. 3436) (2021 Greenhouse Gas Emissions Trading Act of 21 July 2011, Federal Law Gazette I p. 1475). For further relevant EU-level legislation implementing the European Green Deal via the 'Fit for 55' package, see <https://ec.europa.eu/info/strategy/priorities-2019-2024/european-green-deal/ delivering-european-green-deal_en>.

123 Gebäudeenergiegesetz vom 8 August 2020 (B G Bl. I S. 1728) (2020 Building Energy Law of 8 August 2020, Federal Law Gazette I, 1728).

124 Brennstoffemissionshandelsgesetz vom 12 Dezember 2019 (вGBl. I S. 2728), zuletzt geändert durch Artikel 1 des Gesetzes vom 3 November 2020 (BGBl. I S. 2291) (2020 Fuel Emissions Trading Act of 12 December 2019, Federal Law Gazette I, 2728).

125 Baugesetzbuch in der Fassung der Bekanntmachung vom 3 November 2017 (BGBl. I S. 3634), zuletzt geändert durch Artikel 9 des Gesetzes vom 10 September 2021 (в вl. I S. 4147) (2021 Federal Building Code of 3 November 2017, Federal Gazette I, 4147). 
use land-use plans for these purposes. ${ }^{126}$ Further important instruments that municipalities may use to mitigate and adapt to climate change in the building sector and defined in the FBC are urban-development contracts (Section 11) and (re)development by-laws (e.g. Sections 136 and 171a).

In the water sector, German municipalities have significant influence on building-related drinking water demand and supply, waste-water infrastructure, and flood prevention. In all three fields there is overarching regulation at the European and national levels, e.g. setting quality standards for drinking water and waste-water treatment and defining a framework for flood-risk management. Green infrastructure related to buildings is governed by a bundle of legislation covering different aspects. Green roofs for buildings and sealing rates for plots, for example, may be established via land-use plans. Green areas used for drainage might be regulated via land-use planning or flood-prevention regulation. Landscape plans and green-space plans based on natureprotection legislation at the national and state levels are linked to land-use planning and to key tools for municipal green-infrastructure planning that protect buildings from flooding.

\subsubsection{South African Legislation}

As mentioned in the introduction, South Africa is in the process of developing a framework climate change law. The country's Climate Change Bill was opened for public comment in 2018 and is now moving through the legislative process. The Bill will provide a legislative framework to

enable the development of an effective climate change response and a long term, just transition to a climate resilient and low carbon economy and society for South Africa in the context of sustainable development; and to provide for matters connected therewith. ${ }^{127}$

Although there is currently no designated climate change legislation in South Africa, there are several statutes that provide municipalities with a substantive environmental role relevant to climate change mitigation and adaptation. The Local Government (Municipal Systems) Act 2000 obliges municipalities to use strategic planning as the main tool for realizing their environmental mandate.

126 Christoph Diepes and Nikolas Müller, 'Klimarelevante Handlungsfelder in der Verbindlichen Bauleitplanung: Nutzen Deutsche Großstädte den ihnen zur Verfügung Stehenden Handlungsspielraum für Klimaschutz und Anpassung aus?', 3 Zeitschrift für Umweltpolitik und Umweltrecht 288 (2018). 
Each municipal council must adopt an Integrated Development Plan, for the development of the municipality, shortly after the start of its elected term. The IDP must contain the city's development vision, a financial plan, and sector-specific plans that address the needs of communities in areas such as water, health, spatial transformation, disaster management, energy, waste management, and housing. Once adopted, the IDP serves as a decision-making blueprint for the executive, administrative, and political structures of a city.

The National Environmental Management Act 1998 (NEMA) is a framework environmental law that outlines a set of principles to guide the design and implementation of development projects. Although the Act is silent on climate change, its environmental principles are binding on municipalities and are relevant to climate change mitigation and adaptation. The Carbon Tax Act 2019 gives effect to the polluter-pays principle in NEMA, providing for the imposition of a tax on greenhouse gas emissions. The tax also serves as an incentive to reward the efficient use of energy. In the building sector, the tax is imposed on the production of zinc, steel, cement, glass, ceramic, and brick, where emissions exceed thresholds of matching activities in Schedule 2 of the Act. The tax applies to the residential sector where a building uses more than $10 \mathrm{MW}$ (th) per year. ${ }^{128}$ Carbon offsets can be used by taxpayers to reduce the amount of the tax, subject to ministerial regulation. The administration of the Act falls outside the competence of cities.

There is legislation in the energy, water, and green-infrastructure subsectors that relates to buildings. This legislation generally assigns municipalities specific implementation powers and functions. In terms of energy, although ЕSком has a dominant role in electricity generation, the National Energy Regulator of South Africa issues electricity-generation licenses to non-ESKOM power producers pursuant to the Electricity Regulation Act 2006 (ERA). It is envisaged that changes to Schedule 2 of the ERA will allow for the production of up to $100 \mathrm{MW}$ of electricity from renewable sources without the need for a license, irrespective of whether a producer is connected to the grid. ${ }^{129}$ Producers will be allowed to wheel power through the transmission grid subject to wheeling charges and agreements with Е Кком and municipalities. Municipalities will be able to decide whether to approve grid-connection applications in order to ensure grid compliance with their network.

Section 3 and Schedule 2 of the Carbon Tax Act 2019.

129 The Presidency, 'Announcement by President Cyril Ramaphosa on amendment to Schedule 2 of the Electricity Regulations Act', 10 June 2021, <www.thepresidency.gov. $\mathrm{za} /$ speeches/announcement-president-cyril-ramaphosa-amendment-schedule-twoelectricity-regulation-act>. 
In City of Cape Town v. National Energy Regulator of South Africa [NERSA] and Minister of Energy, ${ }^{130}$ the City wanted to purchase more renewable energy from independent power producers (IPPs) without first seeking the consent of the Minister of Energy, as required by Section 34 of the ERA. NERSA argued that, due to this provision, it could not license a new power plant to generate and sell electricity to the City of Cape Town, unless the Minister first determined that such a new facility was needed and may be established. The City had not identified an IPP and there was no application for a license before NERSA for consideration. ${ }^{131}$ The City argued that its approach was in the best interests of the community because it would diversify its energy sources and ensure security of supply. The City also argued that buying electricity from IPPs was more environmentally friendly and costeffective compared to purchasing electricity generated by EsкOM. The City asked the Pretoria Division of the High Court to declare that a Section 34 ministerial determination is not required for an IPP to establish a new power plant and supply it with electricity. ${ }^{132}$ The City argued that if the Court were of the view that such a determination is required, the Court should alternatively declare Section 34 of the ERA unconstitutional as it encroached upon the constitutionally recognized powers and functions of local government in South Africa. It was the City's constitutional right, it claimed, to procure energy in any manner it deemed best, without a ministerial determiniation. ${ }^{133}$ The Court found that the City had failed to comply with the mandatory requirements for resolving intergovernmental disputes in Chapter 3 of the Constitution and in the Intergovernmental Relations Framework Act 2005. ${ }^{134}$ The City had 'failed in its responsibility as an organ of State to avoid litigation.'. ${ }^{35}$ The Court referred the dispute back to the parties, indicating that if all attempts to resolve the dispute pursuant to the relevant laws turned out to be unsuccessful, any of the parties could apply to the Court for leave to relist the application for hearing. ${ }^{136}$

130 (2020) Case No 51765/17 (11 August 2020).

131 Ibid., para 2.

132 Ibid., para 3.

133 Ibid., paras $3-4$.

134 Chapter 3 of the Constitution contains a number of principles in Section 41 that are supposed to guide intergovernmental relations. Pursuant to Section 41(2), the Intergovernmental Relations Framework Act 13 of 2005 was enacted by parliament to create structures to promote and facilitate intergovernmental relations; and to provide for appropriate mechanisms and procedures to facilitate settlement of intergovernmental disputes.

135 Supra note 13 o, para. 42.

136 Ibid., para. 44. 
Although the City of Cape Town did not win the case against NERSA and the Minister of Energy, the litigation seems to have precipitated some changes to the energy regulatory framework. On 16 October 2020, the Minister of Energy gazetted amendments to the Electricity Regulations on New Generation Capacity under the $\mathrm{ERA}^{137}$ that allow municipalities to apply to the Minister of Mineral Resources and Energy for approval to establish new generation capacity. This may happen through an internal mechanism of the municipality or through an external mechanism such as private-sector IPPs. ${ }^{138}$ Where a municipality proposes to use an internal mechanism to procure new generation capacity, it must submit a feasibility study as well as proof that its application is aligned with its Integrated Development Plan. Where it proposes to use an external mechanism, it must, in addition, show that it has complied with the legal framework for public procurement. ${ }^{139}$ New generation capacity in this context includes renewable-energy sources and co-generation; base-load, mid-merit load, and peak-load new generation; energy storage; and cross-jurisdictional projects. ${ }^{140}$ In line with the envisaged changes to Schedule 2 of the ERA, new generation capacity allows for municipalities to produce up to 100 MW of electricity. Barclay argues that most municipalities in the country are not in a financial position to realize the new generation capacity through internal mechanisms. ${ }^{141}$ However, relatively well-resourced municipalities, such as the City of Cape Town, may be able to take advantage of the new regulations to enhance their drive towards decarbonization.

It is worth noting that, in November 2021, the Centre for Environmental Rights (CER) launched a constitutional case on behalf of three applicants (GroundWork, Africa Climate Alliance, and Vukani Environmental Justice Movement in Action) challenging the government's plan to procure $1500 \mathrm{MW}$ of new coal-fired power for the national electricity system. This followed the failure of the Minister of Mineral Resources and Energy and NERSA to respond to a letter of demand that the government's plan be scrapped. CER argued that the government's plan poses significant unjustifiable threats to the constitutional environmental right, given that cleaner and less harmful renewable energy

\footnotetext{
137 See GN R 1093 in GG 43810 of 16 November 2020.

138 Ibid, Regulation 4.

139 Ibid., Regulations 4 and 5.

140 Ibid, Regulation 3.

141 Claire Barclay, 2021, 'South Africa takes further steps to open up electricity market' $<$ www.pinsentmasons.com/out-law/analysis/south-africa-takes-further-steps-to-open-upelectricity-market>.
} 
is a feasible and cheaper alternative to new coal power. ${ }^{142}$ The case relies on expert studies demonstrating the implications, including impacts on climate change, of new coal-fired power for the country. ${ }^{143}$ One of the reports considers how lifestyles and services will be affected by climate change by 2030, 2040, and beyond, with a particular focus on the provinces of Western Cape (where Cape Town is situated), Limpopo, and Mpumalanga. ${ }^{144}$ At the time of writing, the Minister and NERSA were expected to file a record of all documents and information relating to their impugned plan, together with their reasons for adopting it, to the North Gauteng High Court, in December 2021. The applicants would then have an opportunity to amend their application, following which the Minister and NERSA would be expected to announce whether they intend to oppose the relief sought. ${ }^{145}$ If the applicants succeed, this case could limit the government's ability to build new coal-fired power stations.

The installation of small-scale embedded PV generators (SSEG) in buildings is permitted under Schedule 2 of the ERA and is regulated by South African National Standard (SANS) 10142-3. This mostly deals with safety, power quality, and grid operational restrictions. Due to the fact that Schedule $4 \mathrm{~B}$ of the Constitution gives municipalities competence over electricity reticulation, municipalities need to develop an appropriate regulatory framework for SSEGS informed by SANS 10142- 3 .

The National Building Regulations and Building Standards Act 1977 (NBRBS Act) is important in terms of energy consumption. Cities are responsible for implementing this Act. Section 17 gives the Minister of Trade and Industry the power to make national building regulations covering a range of issues, such as heating and lighting of buildings. The Minister promulgated Regulation 7 to introduce Requirements for Energy Usage in Buildings. ${ }^{146}$ The regulation requires that, in order to reduce greenhouse gas emissions, new buildings and extensions should be designed and constructed so as to be capable of using energy efficiently. At least $50 \%$ of the annual average domestic hot-water

CER, 'Youth-led \#CancelCoal climate case launched against government's plans for new coal fired power', 2021, <https://cer.org.za/news/youth-led-cancelcoal-climate-caselaunched-against-governments-plans-for-new-coal-fired-power $>$.

Reports relied on by CER can be accessed at: <https://cer.org.za/wp-content/ uploads/2021/11/ESRG_New-coal-plants-South-Africa_o21121.pdf>; <https://cer.org.za/ wp-content/uploads/2021/og/Climate-impacts-in-South-Africa_Final_September_2021. FINAL_.pdf>; and <https://cer.org.za/wp-content/uploads/2021/og/CER-Export-ReportGarret-Barnwell-Final-3o-August-2021-2.pdf>.

144 For details, see: <https://cer.org.za/wp-content/uploads/2021/og/Nick-King-Report-Final. pdf>.

145 CER, supra note 142.

146 GN R711 in GG 34586 of 9 September 2011. 
requirements of a building should be provided by sustainable energy-efficient means rather than by traditional electrical-element heating. The requirement for energy efficiency in a new building will be met when the design and construction meet national standards (outlined in SANS 10400 Part XA, regulating energy usage in buildings) and when certified thermal-calculation software is used to show that the design and construction of the building will result in a theoretical energy-usage performance less than or equal to that of a reference building in SANS 1040O-XA. ${ }^{147}$ Energy-sector legislation largely emphasizes climate change mitigation, in terms of both the generation and consumption of electricity.

The national government regulates the quality of drinking water. In line with the Constitution, national legislation obliges municipalities to provide potable-water supply services to residents and industries within their jurisdiction. ${ }^{148}$ To address the needs of those living in poverty, municipalities are obliged to provide, freely, a minimum of 25 litres of potable water per person per day, or six kilolitres per household per month. This should be in conjunction with appropriate education regarding effective water use. ${ }^{149}$ Given the frequent droughts experienced in South Africa, municipalities that are drought-stricken will likely not meet this threshold. Municipalities have the power to implement measures to control water consumption. ${ }^{150}$

A metropolitan municipality has exclusive power to provide sanitation and waste-water management services within its jurisdiction. Section 84 of the Local Government (Municipal Structures) Act 1998 specifies how these functions should be divided between local and district municipalities. Closely related is the duty of municipalities to provide storm-water management systems in built-up areas. In general, municipalities are expected to develop, maintain, and upgrade bulk infrastructure needed to effectively provide those services. The lack of experienced or sufficiently qualified personnel across the country makes it difficult for some municipalities to meet compulsory national standards for the construction and functioning of waste-water treatment

147 City of Cape Town, Resource Efficiency for Development (Cape Town: City of Cape Town, 2019), 30-1.

148 Sections 3 and $7-8$ of the Water Services Act 1997.

149 Oliver Fuo, 'The Right of Access to Sufficient Water in South Africa: Comments on Federation for Sustainable Environment and Others $v$ Minister of Water Affairs and Others', 20(2) Murdoch University Law Review 21 (2013), 27; Oliver Fuo, 'Local Government Indigent Policies in the Pursuit of Social Justice in South Africa Through the Lenses of Fraser', 25(1) Stellenbosch Law Review 187 (2014), 196.

Mazibuko and Others v. City of Johannesburg and Others 2010 (3) BCLR 239 (CC), paras $110-11$. 
plants. This affects their optimal functioning and leads to high levels of sewage pollution. ${ }^{151}$ Each municipality is expected to have in place a Storm Water Management Plan that is aligned with its Disaster Management Plan. A flooding disaster must be dealt with in accordance with the Disaster Management Act 2002. Where a local state of disaster is declared, the council of a metropolitan or district municipality, as the case may be, is primarily responsible for coordination and management. The level of involvement of the different spheres of government depends on the severity of the disaster. ${ }^{152}$

The Climate Change White Paper (2011) emphasizes the need to promote integrated planning across all planning regimes of the three spheres of government in order to ensure that climate change considerations and responses are mainstreamed into all relevant sectors. ${ }^{153}$ The White Paper envisages that cities will incorporate thermal efficiency into urban designs, use climateresilient technologies, and support appropriate downscaling of climate models to a scale that can be integrated into municipal spatial-development plans. ${ }^{154}$

The National Climate Change Adaptation Strategy (2019) is the cornerstone for climate change adaptation in the country. ${ }^{155}$ It seeks to provide a coherent, cross-sectoral, and economy-wide approach to adaptation. It outlines four strategic objectives, twelve principles, and nine strategic interventions, to guide the government's adaptation actions. ${ }^{156}$ It acknowledges the role of municipalities in implementing many of the strategic interventions. For example, in order to reduce the vulnerability of human, economic, environmental, physical, and ecological infrastructure and build adaptive capacity, municipalities are expected to work together with other stakeholders to develop, inter alia, resilience-building projects that can easily be replicated; equip and capacitate emergency-response departments to prepare for and manage climate-related disasters; promote the expansion of food-garden programmes; promote the expansion of tree cover, forests, and forest plantations in order to help reduce temperatures in cities; investigate the potential effects of an expanded

151 Nothando Lilian Queen Gopo, Regulation of Wastewater Treatment Plants in the Ba-Phalaborwa Municipality (2013) (unpublished LLM dissertation, North-West University), 30-1.

152 See Sections 42-55 of the Disaster Management Act 2002 (DMA).

153 South Africa Department of Environmental Affairs, National Climate Change Response White Paper (Pretoria: Department of Environmental Affairs, 2011), 15.

154 Ibid., 22.

155 Republic of South Africa Department of Environmental Affairs, National Climate Change Adaptation Strategy (Pretoria: Department of Environmental Affairs, 2019), 20-1.

156 Ibid., 20-1. 
forestry sector on water availability; and implement adaptive water-management strategies. ${ }^{157}$

South Africa's Low Emission Development Strategy 2050 (2020) serves as the country's long-term emission-reduction strategy pursuant to the Paris Agreement. The Strategy describes measures that are currently implemented by government to address mitigation across sectors such as energy, industry, and economy. It acknowledges that many of the measures it mentions 'address only the short term, and are not considered transformational' and that the country has put these measures together 'as a starting point from which to ratchet up our future ambitions towards [a] more integrated, transformational strategy.'.158

From the perspective of national law and policy, South African cities have wide competences cutting across different sectors, such as buildings, energy, water, spatial planning, and disaster management. Their powers and functions in these areas coupled with their responsibility to build the infrastructure needed to deliver related services speak to the fact that, in theory, they could use the building sector to contribute towards climate change mitigation and adaptation. However, ageing municipal infrastructure, inadequate resources, rampant corruption, and limited capacity in most municipalities makes it difficult for them to take full advantage of the enabling legal framework.

Although this overview of national legislation shows heterogeneous approaches to equip municipalities to deal with climate mitigation and adaptation in the building sector, in all three countries the 'climate toolbox' for municipalities offers a diverse range of instruments to promote local resilience and low-emission development. None of the countries oblige municipalities to reach defined emission-reduction targets. The degree of commitment and success in this respect depends on local political will.

\section{4}

State Law

State or regional law can also influence how cities exercise their powers and functions in the building sector.

\footnotetext{
157 Ibid., $62-5$.

158 South Africa, Department of Environmental Affairs Low Emission Development Strategy (Pretoria: Department of Environmental Affairs, 2020), x.
} 


\subsection{Brazilian State Law}

In Brazil the states are competent to regulate all matters not exclusively reserved by the Constitution to other federative entities. ${ }^{159}$ The states, accordingly, have the power to set up their own policies and plans for climate change, ${ }^{160}$ disaster management, ${ }^{161}$ and sanitation, and for the distribution of electricity ${ }^{162}$ and natural gas, ${ }^{163}$ directly or through public concessions. The states are also competent to set up and implement programs for transportation and affordable housing. ${ }^{164}$ Also, as earlier noted, states have the power to create metropolitan regions and to partake in their governance. ${ }^{165}$ Approximately half of Brazil's states have adopted climate change policies. ${ }^{166}$

\subsection{German State Law}

German states share legislative competences with the national level in all main areas related to climate mitigation and adaptation in the building sector. In the field of land law (Bodenrecht) the federal level may overrule state legislation. The Federal Building Code is enacted at the national level based on this competence and regulates municipal land-use planning. However, building regulation related to the safety of buildings, as well as, among other things, requirements and procedures for building permits, is enacted at state level (Landesbauordnungen).

The general scope of responsibility and action of municipalities is regulated at the state level via municipal codes (Gemeindeordnungen). The field of disaster management is mainly governed by state law. Government districts, counties and municipalities are responsible for implementing disaster-management plans. For regional law, nature- and landscape-protection law, and water law, the states may enact legislation even if the federal level has released a law ('deviation legislation competence'). In the case of conflict, the more recent regulation prevails. Thus, state water laws and state nature-protection laws can signifcantly shape municipal climate mitigation and adaptation efforts in the fields of blue and green infrastructure.

\footnotetext{
1591988 Brazilian Constitution, art. 25, para. 1.

16o Ibid., art. 24.VI; 2009 National Climate Change Policy, art. 5.v.

1611988 Brazilian Constitution, art. 23.II.

162 Ibid., art. 21.XII, b.

163 Ibid., art. 25, para. 2.

164 Ibid., art. 23.IX.

165 Ibid., art. 25, para. 3 .

166 Fabiana Barbi and Leila da Costa Ferreira, 'Governing Climate Change Risks: Subnational Climate Policies in Brazil', 2 Chinese Political Science Review 237 (2017).
} 
About half of Germany's states have enacted climate-protection laws that shape municipal climate mitigation and adaptation efforts. ${ }^{167}$ The climateprotection law of Baden-Württemberg, ${ }^{168}$ for example, obliges municipalities to enact heating plans to manage the decarbonization of local heating supply. Many state climate laws establish funding which municipalities can apply for to finance climate mitigation and adaptation measures. The climate plan of the city-state of Hamburg is significantly strengthened by the Hamburg State Climate Protection Act. ${ }^{169}$ It will be discussed in detail in the case-study section below.

\subsection{South African State Law}

The constitutional distribution of powers in South Africa leaves provinces relatively weak when compared to national and local spheres of government. ${ }^{170}$ The nine provincial governments do have powers to regulate how municipalities discharge their functions; ${ }^{171}$ however, they are limited to laying out broad guidelines within which municipalities should exercise their original constitutional powers. Such regulation may not impede a municipality's ability to exercise its powers or perform its functions. ${ }^{172}$

Provincial climate change policies do exist, although there is no provincial climate change legislation. Provincial governments have climate-related strategies and programs in place, with which municipalities are generally required to align their policies and plans. ${ }^{173}$ For example, Western Cape Province adopted a Climate Change Response Strategy in $2014 .{ }^{174}$ The Strategy outlines the vulnerabilities of the province, the climate change response approach adopted by

167 Zengerling, 'Städte', supra note 114, 8f.

168 Klimaschutzgesetz Baden-Württemberg (KSG BW) vom 23 Juli 2013 (GBl. 2013, 229), zuletzt geändert durch Artikel 1 des Gesetzes vom 15 Oktober 2020 (GBl. S. 937) (2020 State Climate Protection Law of Baden-Württember of 23 July 2013, State Law Gazette, 937).

169 Hamburg, 'Hamburgisches Gesetz zum Schutz des Klimas (Hamburgisches Klimaschutzgesetz-HmbKliSchG)', 2o February 2020, <www.landesrecht-hamburg.de/jportal/portal/ page/bshaprod.psml?showdoccase $=1 \&$ doc.id=jlr-KlimaSchGHA2O2orahmen $>\quad(2020$ Hamburg Climate Protection Law of 20 February 2020, hereinafter 2020 Hamburg Climate Protection Law or HCPL).

170 Fuo, supra note 55, 122.

171 Sections $155(6)(a)$ and (7) of the Constitution.

172 Fuo, supra note $56,328-31$.

173 Section 41(iv) of the Constitution; Oliver Fuo, 'A Critical Investigation of the Relevance and Potential of IDPs as a Local Governance Instrument for Pursuing Social Justice in South Africa,' 16(5) Potchefstroom Electronic Law Journal 221 (2013), 230.

174 Western Cape Provincial Government: Western Cape Climate Change Response Strategy (2014). 
the provincial government, and key focus areas. ${ }^{175}$ It acknowledges the need to develop partnerships with municipalities in the province in order to ensure an integrated approach in mitigation-risk reduction and resilient building activities across the province. ${ }^{176}$ The Strategy is under revision and the aim is to finalize the process by $2022 .{ }^{177}$

Provincial governments have no real power over energy generation. There are no provincial building codes. The power of 'provincial planning' is opaque and does not extend to spatial planning within the jurisdiction of municipalities. Pre-democratic provincial planning ordinances which subjected the spatial-planning powers of municipalities to provincial approvals have been replaced by the Spatial Planning and Land Use Management Act 2013. Municipalities have final decision-making power over spatial-planning matters. ${ }^{178}$

Each provincial government is required to have a Disaster Management Framework, a Disaster Management Plan, and a Disaster Management Centre. ${ }^{179} \mathrm{~A}$ provincial government can issue regulations to better manage a disaster in a province. ${ }^{180}$ Provinces can use their disaster-management powers to assist municipalities in water management through the setting of minimum standards or in providing flood relief.

Provinces are legally responsible for the provision of social housing, ${ }^{181}$ with the exception that this function has been delegated to the country's eight metropolitan municipalities. Other municipalities that have the capacity may, subject to approval and allocation of funds by provincial governments, provide social housing. ${ }^{182}$ Municipalities that have the resources can also self-fund social housing. Some provinces, such as Gauteng Province, pay for 10o-litre high-pressure solar geysers to be fitted into new social housing.

This short section's overview shows that in Brazil and Germany states have a significant scope of action to shape municipal climate mitigation and adaptation efforts related to buildings and to building-related energy, water, and green infrastructure. In South Africa, the constitutionally defined scope of

\footnotetext{
175 Ibid., 8-10 and 21-38.

176 Ibid., 39 .

177 Western Cape Government, 'Climate Change', 2021 <www.westerncape.gov.za/eadp/ about-us/meet-chief-directorates/environmental-sustainability/climate-change>.

178 Minister of Local Government, Environmental Affairs and Development Planning, Western Cape v. Habitat Council and Others 2014 (4) SA 437 (CC), para. 19.

179 Section 28 of the DMA.

180 See generally Sections $28-41$ of the DMA.

181 South Africa Department of Human Settlements, National Housing Code (Pretoria: The Department, 2009), 21.

Ibid.
} 
action of provinces is rather narrow compared to the national and local level; the building-related influence of provinces can be found mainly in the fields of disaster management and social housing.

In this section we concisely present key elements of ongoing climate mitigation and adaptation efforts in the building sector and in the related subsectors of energy, water, and green infrastructure in Cape Town, Hamburg, and São Paulo. We aim to provide insights into how these cities are using their constitutional and legislative competences in these areas, highlighting synergies, conflicts, and challenges for climate mitigation and adaptation measures in the building sector, as well as the room for improvement.

\subsection{City of Cape Town, South Africa}

The City of Cape Town is home to about four million people and about 1.265 million households. The City regularly experiences droughts. The most recent severe drought was between mid-2017 and mid-2018 when the City almost ran out of water. ${ }^{183}$ Residents of informal settlements, built on flood plains and wetlands, regularly experience flooding during winter rains. Droughts and flooding are expected to intensify due to climate change. ${ }^{184}$

The Climate Change Policy of the City of Cape Town (2017) estimates that the City's per-capita energy-related emission footprint for 2012 was $5.2 \mathrm{t} \mathrm{CO}_{2}$ eq. ${ }^{185}$ This represents a drop from the estimate for 2001 of $5.7 \mathrm{t} \mathrm{CO}_{2}$ eq. and from the estimate for 2007 of $6.1 \mathrm{t} \mathrm{CO}_{2}$ eq. ${ }^{186}$ The decline is attributed to a number of factors, including increase in electricity costs, increase in energy efficiency, and widespread behaviour-change campaigns implemented by the City. ${ }^{187}$ The City's building sector accounts for about $33 \%$ of energy consumption and $58 \%$ of $\mathrm{CO}_{2}$ emissions. ${ }^{188}$ The City's residential sector is responsible for about

183 City of Cape Town, Water Strategy (Cape Town: City of Cape Town, 2019), 2-3.

184 Ibid.; see City of Cape Town, Climate Change Policy (Cape Town: City of Cape Town, 2017) at $6-12$.

185 Including marine and aviation fuels, it stood at $5.55 \mathrm{t} \mathrm{CO}_{2}$ eq. in 2012; see City of Cape Town, Climate Change Policy, supra note 184, 12. See also Invest Cape Town, 'Cape Town Reduces Its Carbon Emissions by $4.1 \%$ as It Ramps Up Climate Change Mitigation Efforts', 12 August 2018, <www.investcapetown.com/press_release/press-releases-one-title/>. The 2001 and 2007 figures exclude marine and aviation fuels; see City of Cape Town, Climate Change Policy, supra note 184, 12. Ibid.

188 City of Cape Town, Resource Efficiency, supra note 147, 29. 
$15 \%$ of total energy use. ${ }^{189}$ The City projects that its greenhouse gas emissions will peak in 2035 and thereafter begin to decline; and it aims to achieve climate neutrality by 2050.190

The City's Climate Change Policy provides the overarching framework for climate action. Its underlying principle is to take a balanced, and, where possible, synergistic approach to climate change mitigation and adaptation. This includes promoting climate-compatible urban design and infrastructure development and maintenance. ${ }^{191}$ The Policy is complemented by the City's Integrated Development Plan. ${ }^{192}$ The current IDP sets out a vision of what the City aspires to achieve by June 2022. Several of the IDP's priority areas seek to respond to climate change. ${ }^{193}$ The City has adopted several policies, plans, and by-laws to address climate change in the building sector. It is implementing SANS 10400-XA, regulating energy use in buildings. The City's regulatory framework for climate mitigation and adaptation is highly fragmented.

\subsubsection{Energy}

Cape Town mitigates $\mathrm{CO}_{2}$ emissions in the energy sector by promoting energy-efficiency measures and the use of renewable energy. It has implemented energy-efficiency measures for its street and traffic lighting, energy-efficiency retrofits for its buildings, smart metering in its facilities, an energy data management system, and behaviour-change training for managers in its facilities. ${ }^{194}$

The City has requirements for energy efficiency to be met by new applicants for electricity supply and by those seeking to upgrade their supply.195 These applicants are prohibited from using incandescent or other inefficient lighting technologies. New applicants are required to use the most efficient lamp that can meet the required level of illumination, and must use only solar water heating and heat-pump technologies. Applicants for new or upgraded electricity supply must insulate hot-water pipes and hot-water storage tanks, and correctly use functioning thermostatic controls, which are to be set at the most

\footnotetext{
$189 \quad$ Ibid.

190 City of Cape Town, 'Carbon Neutral 2050 Commitment', 2020, <https://resource.capetown. gov.za/documentcentre/Documents/City\%2ostrategies\%2c\%2oplans\%2oand\%20 frameworks/Carbon_Neutral_2050_Commitment.pdf>.

191 City of Cape Town, Climate Change Policy, supra note 184, 24.

192 City of Cape Town, Five-Year Integrated Development Plan (Cape Town: City of Cape Town, 2017).

193 Ibid., 32-42.

194 Ibid., 37.

195 See City of Cape Town, Energy Efficiency Requirements (Cape Town: City of Cape Town, 2014); and City of Cape Town, Resource Efficiency, supra note 147.
} 
efficient level. ${ }^{196}$ The City requires that applicants for electricity connection to new buildings should employ a load-management system to interrupt nonessential loads when possible, use energy-efficient glass or appropriate film, and design electrical installations to ensure that non-essential loads are grouped on the same circuit in order to ensure that the City can in the future facilitate remote shedding of non-essential circuits using smart-meter technology. ${ }^{197}$ All new government-subsidized houses for the poor are expected to meet basic requirements that improve their thermal performance. ${ }^{198}$

In terms of renewable energy, the City encourages the installation of private Small-Scale Embedded Generation (SSEG), especially rooftop PV systems. ${ }^{199}$ Developers who want to install SSEG systems (PV, micro-hydro, or wind turbines) smaller than 1 MVA need to comply with the relevant City policy. Developers can install one of three SSEG options: a grid-tied, feed-in system, where electricity generated is used on the property and any excess is fed into the electricity grid; a grid-tied, non-feed-in system, where electricity generated is used only when there is a demand for it; and an off-grid or standalone PV system. ${ }^{200}$ The target for 2020 was to ensure that 120 MW SSEG in the form of rooftop PV systems was installed in the commercial sector. ${ }^{201}$ The City will need to revise its policy in light of an amendment to Schedule 2 of the Electricity Regulation Act which allows independent power producers to generate up to $100 \mathrm{MW}$ of electricity from renewable sources. The City is willing to purchase renewable energy directly from independent power producers at a cost no higher than that of purchasing electricity from ESком. ${ }^{202}$

Some of the City's energy-efficiency requirements also serve an adaptation purpose by minimizing heat effects and promoting natural cooling in buildings. For example, applicants for new or upgraded electricity supply are required to insulate walls, ceilings, and roofs, as well as increase light reflectance on walls and ceilings, use daylight whenever possible instead of artificial light, shade

196 City of Cape Town, Resource Efficiency, supra note 147, 31-5.

197 Ibid.

198 Ibid., 3 .

199 See City of Cape Town, 'Requirements for Small-Scale Embedded Generator in the City of Cape Town: Application Process to Become a Small-Scale Embedded Generator in the City of Cape Town', 21 August 2017, <https://resource.capetown.gov.za/documentcentre/ Documents/Procedures\%2C\%2oguidelines\%2oand\%2oregulations/Requiremenst\%2o for\%2oSamll-Scale\%2oEmbedded\%2oGeneration.pdf >; City of Cape Town, 'Rooftop PV: Guidelines for Safe and Legal Installations in Cape Town', 2018, <www.sseg.org.za/ rooftop-pv-guidelines-for-safe-and-legal-installations-in-cape-town/>.

200 City of Cape Town, Resource Efficiency, supra note 147, 36-8.

201 City of Cape Town, IDP, supra note 192, 76.

202 Ibid. 
windows from direct sunlight in new buildings, and where possible orientate new buildings to maximize energy efficiency. ${ }^{203}$

The uptake of solar PV and SSEG systems by households in South Africa remains low, hindered by high upfront capital costs. ${ }^{204}$ Energy demand continues to grow as a result of the City's fast growing economy. The energy supply in informal settlements remains a challenge because some of them are not connected to the electricity grid. ${ }^{205}$

\subsubsection{Water}

Cape Town's Water Strategy (2019) is the most comprehensive instrument dealing with adaptation in the water sector. The City promotes water conservation through a variety of measures, such as water pricing, use of planning requirements to incentivize water efficiency, treatment and reuse of water, and managing and maintaining water networks to reduce losses. Section 21 of the City's Amended Water By-Law of 2018 prescribes that new buildings are to instal water-conservation and water-demand management systems, or that alternative water systems (such as greywater collection, rainwater harvesting, treated wastewater, and ground water) are incorporated into the building plan. Water-sensitive urban design principles seek to ensure that development sustainably integrates all components of the urban water cycle. ${ }^{206}$ The City has developed large water-storage infrastructure, including dams, and plans to develop new and diverse supplies of water, including ground water and desalination facilities. ${ }^{207}$ The City is leading a feasibility study for a permanent desalination plant with a capacity of between 50 and 150 million litres per day. ${ }^{208}$ Two temporary desalination plants built by the City in the midst of the 2017-2018 drought have been decommissioned. The City's contribution to climate change mitigation in this sector will depend on whether desalination contracts are awarded to companies that can source their energy from renewable sources, instead of relying on ЕSком for power.

\footnotetext{
203 City of Cape Town, Resource Efficiency, supra note 147, 31-5.

204 Silas K. Mulaudzi, Steve Bull, and Rudzani A. Makhado, 'Potential of Households' Solar PV Consumption in South Africa', African Journal of Science, Technology, Innovation and Development 1 (2021), 4-7.

205 City of Cape Town, Resource Efficiency, supra note 147, 30.

206 City of Cape Town, Climate Change Policy, supra note 184, 18.

207 Ibid., 20; City of Cape Town, Water Strategy, supra note 183, 5.

208 City of Cape Town, Climate Change Policy, supra note 184, 37.
} 


\subsubsection{Green Infrastructure}

Promoting climate-compatible urban design as well as infrastructure design and maintenance is a major priority for the City of Cape Town. The City seeks to 'use its planning, operating, investment and regulatory powers to directly and indirectly improve the design of infrastructure and urban space, spatial transformation and integration of the city, in order to increase urban efficiency'. ${ }^{209}$ The Climate Change Policy directs the City to implement resource-efficiency and climate-impact considerations in the design, development, and renovation of City infrastructure where possible. It also directs the City to include climate-impact considerations in building-development approvals. ${ }^{210}$ The City has adopted a best-practice guideline to promote development of green infrastructure, largely focusing on increasing green spaces. ${ }^{211}$

The City envisages that the promotion of transit-oriented development (TOD) will create a more compact and efficient urban form. TOD in the City is about 'changing, developing and stimulating the built form of the city so that the movement patterns of people and goods are optimised in order to create urban efficiencies and enable social equality and economic development'. ${ }^{212}$ The goal is to avoid urban sprawl and to enhance access for all citizens to a quality open-space network using non-motorized transport. ${ }^{213}$ However, overcoming injustices in the City's spatial history remains a major challenge. Highdensity, predominantly Black, townships lie on the outskirts of the City. They are impoverished and far removed from employment opportunities and their residents have to commute to the inner city for jobs. This leads to high emissions from transport. Significant resources are needed for the integration and greening of Black townships. New informal settlements on unsuitable land are mushrooming on the outskirts.

The City of Cape Town uses its spatial-planning powers to implement adaptation measures. ${ }^{214}$ Applications for new developments or for upgrading landuse rights must show that they are in close proximity to open spaces, avoid negative impacts on important natural assets, and avoid risk factors such as flood-lines. In planning new neighbourhoods, the City requires that open

\footnotetext{
209 City of Cape Town, Climate Change Policy, supra note 184, 24.

210 Ibid., 24-5.

211 City of Cape Town, Green Infrastructure Programme Best Practice Guidelines: Trees (Cape Town: City of Cape Town, 2020). City of Cape Town, IDP, supra note 192, 38; City of Cape Town, Climate Change Policy, supra note 184,21 .

213 City of Cape Town, Municipal Spatial Development Framework (Cape Town: City of Cape Town, 2018), 35, 57, and 65 . Ibid., 57 .
} 
spaces (parks and natural or ecological areas) are to be consolidated into well-defined networks of interrelated spaces that are undisturbed by development to support biodiversity. Developments are to aim at combining and connecting open-space uses, such as urban drainage systems, playgrounds, and allotment gardens in order to promote more effective and increased shared use. ${ }^{215}$ The City aims to increase the provision of new ecological infrastructure, such as artificial wetlands, to improve ecosystem resilience. ${ }^{216}$

In terms of storm-water management, the design of new developments in the City is to be consistent with the natural drainage patterns of the site and apply principles of water-sensitive urban design in order to arrive at a layout that is water-sensitive and space-efficient. This is to ensure minimal disruption of the natural hydrological cycle and coordination with the sewerage system. ${ }^{217} \mathrm{New}$ developments beyond a certain size are required to follow sustainable urban-drainage principles in their design so as to manage storm-water run-off on site. For example, large-scale developments must include treatment trains to improve water quality and allow for onsite storage of storm water. ${ }^{218}$ Sections 3-5 of the Stormwater Management By-Law (2005) prohibit, for example, the discharge of anything other than storm water into the stormwater system of the City without written permission; they also prohibit the obstruction or reduction in the capacity of the storm-water system. Despite laws and policies, however, it is difficult to implement storm-water management best practices in the impoverished informal settlements. ${ }^{219}$

As required by national legislation, the City has a Municipal Disaster Risk Management Plan (2015) and a Disaster Risk Management Centre. The Plan is part of the City's IDP and requires various municipal departments to compile sectoral disaster risk-management programmes for disaster-risk reduction and disaster preparedness. ${ }^{220}$ Flooding is a regular disaster, experienced especially in the informal settlements.

215 City of Cape Town, Resource Efficiency, supra note 147, 41-2, 45; City of Cape Town, 'Design and Management Guidelines for a Safer City: Best Practice Guidelines for the Creation of Sustainable, Safe and Lively Neighbourhoods in Cape Town', date unknown, <https:// resource.capetown.gov.za/documentcentre/Documents/Procedures,\%2oguidelines\%2o and\%2oregulations/Design\%2oand\%2oManagement\%2oGuidelines\%2ofor\%20a\%2o Safer\%2oCity.pdf>, 12, 30-2.

216 City of Cape Town, Climate Change Policy, supra note 184, 22.

217 City of Cape Town, Resource Efficiency, supra note 147, 42.

218 Ibid., 44.

219 City of Cape Town, Management of Stormwater Impacts Policy (Cape Town: City of Cape Town, 2009), 8.

220 City of Cape Town, Municipal Disaster Risk Management Plan (Cape Town: City of Cape Town, 2015), 20. 
The City of Cape Town has set ambitious climate-related goals and has adopted and is implementing a diverse range of instruments to achieve its objectives in the building sector and the related sub-sectors. The goal of zero emissions by 2050 is a tall order which is unlikely to be achieved. It would require a major transformation in urban form, energy sources, and transportation, amongst other things. It is doubtful that the City could transition exclusively to renewable energy by 2050 or convince local manufacturers and importers of buses, cars, and trucks to switch over fully to electrification. The local regulatory framework is highly fragmented. The economic growth rate of the City, which far exceeds the national average, requires more electricity to power it. The associated growth of informal settlements and the frequent occurrence of droughts and floods are major issues for the City. Addressing them requires more than legal rules, plans, and policies. Concerted action is required across all three spheres of government, and between government and the private sector.

\subsection{Hamburg, Germany}

The second largest city in Germany, Hamburg has over 1.8 million people and more than a million households. Per-capita annual $\mathrm{CO}_{2}$ emissions in 2019 were slightly above 8 tonnes (reduced from 12.5 tonnes in the base year 1990). ${ }^{221}$ The sectors of private households, commerce, and services jointly accounted for about $43 \%$ of the City's roughly $16 \mathrm{Mt} \mathrm{CO}_{2}$ in $2019 .{ }^{222}$ The largest share of $\mathrm{CO}_{2}$ emissions within these sectors (more than $50 \%$ ) came from heating and hot-water supply (using gas, district heating, or individual oil heating) and electricity consumption. Climate change will increasingly affect the water budget, urban climate, tree stock, and green spaces in Hamburg. Floods and heavy-rain events, as well as heat and drought periods, require adaptation of the blue, green, and grey infrastructure.

The City has enacted evolving climate plans since 2007. ${ }^{223}$ The City's recent climate plans integrate climate mitigation and adaptation measures. The Hamburg Climate Commission (Leitstelle Klima), located within the Hamburg

See Hamburg, 'Bilanz des Statistikamtes-Nord für $2019 \mathrm{CO}_{2}$-Emissionen in Hamburg', 2021, $<$ www.hamburg.de/co2-bilanz-hh/>. Hamburg's $\mathrm{CO}_{2}$ inventory follows the methodology agreed on by Germany's federal states. It accounts only for $\mathrm{CO}_{2}$ emissions. Ibid. Followed by the sectors of transport (30\%) and industry $(27 \%)$.

223 City of Hamburg, 'First Revision of the Hamburg Climate Plan', 2019, <www.hamburg.de/ klimaplan/> (available in English, annexes only in German) (hereinafter 2019 Hamburg Climate Plan). For an overview and assessment of past climate-mitigation efforts, see Hamburg, 'Hamburg hat seine Klimaziele Erreicht', 2020, <www.hamburg.de/masterplanklimaschutz/3959612/fortschreibung-klimaschutzkonzept.html>. 
Ministry of Environment, Climate, Energy, and Agriculture, is the main coordinating body for strategically steering climate mitigation and adaptation efforts. The 2019 Climate Plan sets more-ambitious $\mathrm{CO}_{2}$-reduction targets than its predecessors. The City aims to reduce $55 \%$ of its $\mathrm{CO}_{2}$ emissions by 2030 (compared with 1990) and reach climate neutrality by 2050 , measured through final energy consumption. ${ }^{224}$ For the first time, the 2019 Plan also sets sectoral targets for the year 2030 for mobility, industry, commerce and services, and private households. ${ }^{225}$

Hamburg aims to become a climate-resilient city. ${ }^{226}$ The 2019 Climate Plan includes measures to protect against immediate climate impacts, e.g. stormsurge warnings, heat warnings, and climate-adapted development of urban infrastructure, such as heat-resistant road surfaces and safe drinking-water supply. Several of the seven Hamburg districts have enacted or are in the process of developing local climate action plans.

Hamburg as a city-state has enacted the Hamburg Climate Protection Law $2020 .{ }^{227}$ Prior to this law, the City's climate plans were informal, as no legislative act prescribed their content or legal effect. The law adopts the overall and sectoral $\mathrm{CO}_{2}$ emission-reduction targets of the 2019 Climate Plan, making them legally binding. It also formalizes the Plan, referring to it as the key strategic steering tool for the City's climate mitigation and adaptation efforts, prescribes minimum procedural requirements in relation to it (on public participation, biennial progress reports, and quadrennial renewal), and makes it binding on the executive and the judiciary. ${ }^{228}$

The City utilizes land-use plans, urban-development contracts, and property-purchase agreements as key legal instruments to implement building-related climate mitigation and adaptation measures. Innovative planning procedures that emphasize ab initio climate-responsive planning have gained in importance in urban-development projects (e.g. in concept development and in all bidding procedures). ${ }^{229}$

\footnotetext{
2242019 Hamburg Climate Plan, supra note 223, 14.

225 Ibid., 17.

226 Ibid., 48.

227 So far, the 2020 Hamburg Climate Protection Law, supra note 169 , is only available in German. See also Martin Wickel, 'Das Neue Hamburgische Klimaschutzgesetz', 4 NordÖR-Zeitschrift für öffentliches Recht in Norddeutschland 157 (2020).

228 Ibid., 157.

229 See, for example, current planning in Grasbrook (Grasbrook, 'Project Overview', 2020, $<$ www.grasbrook.de/en/project-overview/>).
} 


\subsubsection{Energy}

In order to reach the sectoral $\mathrm{CO}_{2}$ emission-reduction targets for private households and trade and services, the 2019 Climate Plan establishes a Transformation Pathway, 'Heating and Buildings', fleshed out in an annex to the plan. Since about a quarter of Hamburg's $\mathrm{CO}_{2}$ emissions are from space and water heating, 'heat transition' is key. Measures include a sharp reduction in oil heating in private households, a rise in district heating, gas heating, and heat pumps, and refurbishment of building envelopes.

The City's Climate Protection Law supports this transformation pathway in several ways. It tasks the executive with planning for heating and cooling in line with the $\mathrm{CO}_{2}$ emission-reduction targets, and it highlights the need for close cooperation with urban-development and land-use planning. ${ }^{230}$ It also empowers the Hamburg Senate to establish compulsory connection to heating grids in designated areas of the City. ${ }^{231}$ In addition, Hamburg and energy suppliers owned by the City pledge to phase out coal-based combined heat and power by 2030 at the latest. ${ }^{232}$ Finally, all heat suppliers must submit decarbonization plans through to 2024 in line with the target of a nearly climateneutral heat supply by 2050; and they must publish from mid-2020 onward the $\mathrm{CO}_{2}$ factor, renewable-energy share, and primary-energy factor of their heating grids. ${ }^{233}$ All this information feeds into a city-wide 'heat registry'. ${ }^{234}$ Sections 11-19 of the Climate Protection Law are dedicated to renewable energy and buildings and encompass a range of measures, ${ }^{235}$ including financial support for low-carbon building materials, energy-efficiency requirements, an obligation on property owners to install solar-energy systems on the rooftops of new buildings from 2023 onward and, in the case of roof renewal, on existing buildings from 2025 onward, as well as an obligation on property owners to cover $15 \%$ of annual thermal energy demand from renewable energy from mid-2021 onward in the event of renewal of their heating system. With regard to public buildings, the Climate Protection Law sets requirements to work towards a climate-neutral state administration by $2030 .{ }^{236}$

\footnotetext{
230 HCPL, supra note 169 , Section 25 .

231 Ibid., Section 8.

232 Ibid., Section 9.

233 Ibid., Section 10.

234 Ibid., Section 26.

235 Sections 11-13 of the HCPL are mere placeholders so far, since the planned regulationsincluding a prohibition of electric heating and new oil heating-require a notification procedure under EU law which still needs to be completed; see Wickel, supra note 227, 163 .

236 HCPL, supra note 169 , Sections 20-24. However, it is important to note that heating of public buildings is exempted from this target.
} 


\subsubsection{Water}

Located on the river Elbe not far from the North Sea, Hamburg faces several water-related risks from climate change, ranging from storm surges and flooding to unsafe drinking-water supply. The 2019 Climate Plan dedicates a chapter and a Climate Adaptation Transformation Pathway annex to measures in the field of water and green-infrastructure management. Measures are not as detailed as in the field of climate mitigation, but still comprise a bundle of important next steps, all directly or indirectly linked to buildings. The Climate Protection Law, which mainly focuses on climate-mitigation measures, dedicates only one general section to climate adaptation. It states that the Hamburg Senate is to take climate adaptation into account in its decision-making and is to implement the adaptation measures in the 2019 Climate Plan.

The overall water-management concept follows the principles of a 'sponge city' and aims at decentralized rainwater management. Most of the measures build on, or were already prescribed in, the Hamburg Rainwater Infrastructure Adaptation structural plan for rainwater, released after a six-year research project in 2015. ${ }^{237}$ Among the main measures are the establishment of two new planning instruments: a city-wide structural water plan (Wasserplan), encompassing water and waste-water issues, and project-specific supportive water-management plans (wasserwirtschaftliche Begleitpläne). The aim is to integrate these plans with other overarching and local plans. For example, one of the success indicators of this measure is the number of land-use plans and urban-development contracts having a linked water-management plan.

Other measures encompass decentralized rainwater management in public and private spaces, coastal and inland flood protection as required by the EU Floods Directive (2007/6o/EG), including identification of flood-risk areas and updating of flood-risk maps and management plans. Since most of the City's waste-water system is an admixed sewage system, important measures in the field of waste-water disposal include an increased capacity for waste-water storage in case of heavy rain and storm surges. Still other measures relate to saving drinking-water supply, the protection of energy infrastructure, and disaster-prevention and protection management, including new warning systems and disaster funds. ${ }^{238}$ The implementation of several of these measures will require amendments to Hamburg's water and waste-water laws.

\footnotetext{
237 RISA, 'Strukturplan Regenwasser 2030', 2015, <www.risa-hamburg.de/fileadmin/risa/ Downloads/BUE_HSE_2015_RISA_Strukturplan_Regenwasser_203o.pdf $>$.

2382019 Hamburg Climate Plan, supra note 223, 51.
} 


\subsubsection{Green Infrastructure}

The climate-adaptation section of Hamburg's 2019 Climate Plan also highlights the importance of protection and expansion of urban green infrastructure. ${ }^{239}$ The green infrastructure of Hamburg is planned through a landscaping program and through related maps and planning documents. In recent years the topics of heat prevention and promotion of natural water cycles have been integrated into landscape planning and bundled into a green-network map. ${ }^{240}$ This map highlights areas of heat islands, cold-air corridors, as well as spaces with high infiltration potential. In 2014 Hamburg developed a green-roof strategy and plans to build 100 hectares of green roofs by 2024. The Climate Plan mentions that the green-roof strategy will be complemented by a green-façade strategy. As of June 2020 the City offers funding for green façades of up to $40 \%$ of the cost, in addition to green roof funding, via the Hamburg Investment and Development Bank. ${ }^{241}$ Another important field of action is the protection and expansion of urban trees and the rewetting of peatlands. ${ }^{242}$ The City also aims to initiate several pilot projects in the field of integrated green- and blue-infrastructure planning. With direct relevance to the building sector, in 2018 the Hamburg Climate Commission and the Hamburg Chamber of Trade established an expert group of craftsmen, architects, engineers, energy consultants, and planners to consider building-related measures of climate adaptation that could be implemented in new buildings, conversions, or renovations. ${ }^{243}$

The above survey of building-related climate mitigation and adaptation planning in Hamburg shows that the City's 2019 Climate Plan and 2020 Climate Law mainly target the reduction of greenhouse gas emissions through a broad range of climate-mitigation measures. Improving the energy efficiency of buildings and switching from fossil fuels to renewable electricity and heat are central aims. Climate adaptation measures mainly link to already existing initiatives, such as the rainwater-management program, implementation of the EU Floods Directive, and landscape planning. There are several adaptation/mitigation synergies in the expansion of blue and green infrastructure. For example, green areas improve infiltration rates and at the same time

\footnotetext{
239 Ibid., 52.

240 Hamburg, 'Grün Vernetzen', no date, <www.hamburg.de/gruenes-netz/13046992/ karte-gruen-vernetzen/>.

241 Information on the respective funding guideline is avalable at Hamburg, 'Förderung Grüner Fassaden', no date, <www.hamburg.de/foerderung/13871398/ foerderung-gruener-fassaden/>.

2422019 Hamburg Climate Plan, supra note 223, 52. For further information on trees, see Hamburg, 'Bäume', no date, <www.hamburg.de/baeume/>.

2432019 Hamburg Climate Plan, supra note 223, 52.
} 
reduce heat-island effects and contribute to carbon sequestration. On the other hand, conflicts in building-related mitigation and adaptation planning arise in the 'compact city' and 'sponge city' rationales, ${ }^{244}$ in higher electricity consumption for cooling demand, and in the emissions embodied in centralized water-management infrastructure such as waste-water storage. There is also 'competition' between PV arrays and green roofs. Among the main challenges of building-related climate mitigation and adaptation measures is that many of them are still in the hands of home owners and renters, and the citystate has no direct influence on their decision-making. Furthermore, bearing in mind that $80 \%$ of flats in Hamburg are rented, the so-called 'user-investor dilemma' is a crucial obstacle for effective climate mitigation and adaptation measures in buildings. ${ }^{245}$

\subsection{São Paulo, Brazil}

São Paulo, the capital of the state of São Paulo, is the largest and richest city in Brazil. It has a population of 12 million, in a 1,521 km² territory. ${ }^{246}$ According to the City's third greenhouse gas emission inventory (2019), emissions in 2017 amounted to $15 \mathrm{Mt} \mathrm{CO}_{2}$ eq., $61 \%$ produced by the transportation sector, $31 \%$ by the stationary-energy sector, and $8 \%$ by the waste sector. ${ }^{247}$

Intense urbanization, soil impermeability, and deforestation have caused significant changes in the City's rainfall patterns and average temperature. Extreme climate events in the City have increased in intensity and frequency:

244 Among the key characterstics of a 'compact city' are dense and proximate development patterns that are linked to accessible public transport, avoiding urban sprawl. This kind of compactness is associated with a number of positive effects, including reduced greenhouse gas emissions due to lower emissions from transport and buildings; see OECD Policy Brief, Compact Cities Policies: A comparative Assessment, 2012, <www.oecd.org/cfe/ regionaldevelopment/50524895.pdf $>$. The concept of a 'sponge city' refers to a city system that absorbs water, for example via decentralized rainwater management, contiguous open green spaces, green roofs, and general porous cityscape design. It is a key concept in urban climate adaptation planning; see World Future Council for a concise definition, $<$ www.worldfuturecouncil.org/sponge-cities-what-is-it-all-about/>. The rationales of compact and sponge cities are conflicting to a certain degree in their different approaches to space and density.

245 Among the existing approaches to overcome the 'user-investor dilemma' are a rule in federal tenancy law allowing landlords to raise the rent after substantial renovations, as well as third-party involvement in the energy supply, referred to as 'energy contracting' in Germany. Such approaches are helpful, but not sufficient to overcome the dilemma.

246 IBGE, 'São Paulo: População', no date, <https://cidades.ibge.gov.br/brasil/sp/sao-paulo/ panorama>.

247 Prefeitura De São Paulo, PlanClimaSP: Plano Climático de São Paulo (São Paulo: PMSP, 2021) (hereinafter PlanClimaSP), 99. 
longer dry periods, with severe water scarcity, interspersed by extreme rainfall, causing floods and landslides. ${ }^{248}$ Social inequities present severe challenges to climate change adaptation, as the vulnerable population living in informal settlements, located in the periphery as well as in degraded central areas, is the most exposed to climate change hazards and impacts. ${ }^{249}$

Climate action in São Paulo was influenced by its engagement with transnational city networks, such as ICLEI and $\mathrm{C}_{40} \mathrm{O}^{250}$ Climate mitigation and adaptation actions are outlined in the 2009 Climate Change Municipal Law and detailed in other municipal policies, laws, and regulations, such as the 2014 Master Plan, ${ }^{251}$ the 2016 Zoning Law, ${ }^{252}$ the 2017 Building Code, ${ }^{253}$ and the 2020 Climate Action Plan. ${ }^{254}$

Despite having been the first Brazilian city to approve a municipal law on climate change, ${ }^{255}$ it took São Paulo more than ten years to come up with a full

248 Carlos Afonso Nobre, et al., 'Vulnerability of Brazilian Megacities to Climate Change: The São Paulo Metropolitan Region (RMSP)', in Climate Change in Brazil: Economic, Social and Regulatory Aspects, edited by Ronaldo Seroa da Motta et al. (Brasília: IPEA, 2011), 197-219. See also Gabriela Narcizo de Lima and Víctor Orlando Magaña Rueda, 'The Urban Growth of the Metropolitan Area of Sao Paulo and Its Impact on the Climate', 21 Weather and Climate Extremes 17 (2018).

249 Andrea Ferraz Young and Carlos Afonso Nobre, 'Mapping Risk and Vulnerability in São Paulo Metropolitan Region', in Resilient Cities 2: Cities and Adaptation to Climate Change: Proceedings of the Global Forum 2011, edited by Konrad Otto-Zimmermann (Dordrecht: Springer, 2012). See also Jose A. Marengo, Lincoln M. Alves, Tercio Ambrizzi, Andrea Young, Naurinete J. C. Barreto, and Andrea M. Ramos, 'Trends in Extreme Rainfall and Hydrogeometeorological Disasters in the Metropolitan Area of São Paulo: A Review', 1472(1) Annals of the New York Academy of Sciences 5 (2020).

250 Ana Mauad and Michele Betsill, 'A Changing Role in Global Climate Governance: São Paulo Mixing its Climate and International Policies', 62(2) Revista Brasileira de Política Internacional 1 (2019); Laura Silvia Valente de Macedo, Joana Setzer, and Fernando Rei, 'Transnational Action Fostering Climate Protection in the City of São Paulo and Beyond', 52 disP: The Planning Review 35 (2016).

251 Prefeitura de São Paulo, 'Lei no 16.05o, de 31 de julho de 2014', 2014, <http://legislacao. prefeitura.sp.gov.br/leis/lei-16o5o-de-31-de-julho-de-2014> (Municipality of São Paulo, Law 16.05o of 31 July 2014; hereinafter 2014 Master Plan).

252 Prefeitura de São Paulo, 'Lei no 16.402, de 22 de março de 2016', 2016, <http://legislacao. prefeitura.sp.gov.br/leis/lei-16402-de-22-de-marco-de-2016> (Municipality of São Paulo, Law 16.402, of 22 March 2016; hereinafter 2016 Zoning Law).

253 Prefeitura de São Paulo,' Lei no 16.642, de 9 de maio de 2017', 2017, <http://legislacao. prefeitura.sp.gov.br/leis/lei-16642-de-o9-de-maio-de-2017> (Municipality of São Paulo, Law 16.642, of 9 May 2017; hereinafter 2017 Building Code).

254 PlanClimaSP, supra note 247.

255 Prefeitura de São Paulo, 'Lei no 14.933, de 5 de junho de 2009', 2009, <http://legislacao. prefeitura.sp.gov.br/leis/lei-14933-de-o5-de-junho-de-20o9> (Municipality of São Paulo, Law 14.933, of 5 June 2009; hereinafter 2009 Climate Change Law). 
climate action plan. Lack of political will and inconsistencies in political commitments are serious obstacles for advancing climate action in São Paulo. ${ }^{256}$ Whereas the 2009 Climate Change Law was the result of a two-year participatory process, ${ }^{257}$ the 2020 Climate Action Plan, published in 2021 in the midst of the COVID-19 pandemic, is mostly the product of technical inputs from professional stakeholders, such as experts, NGOs, consultants, and high-level city bureaucrats.

The 2020 Climate Action Plan aims to achieve two general goals, through the development of five strategies, each encompassing specific mitigation and adaptation targets and actions. The first general goal is a $50 \%$ reduction of emissions in the Municipality of São Paulo by 2030, compared to 2017 levels, with the complementary goal to achieve zero emissions in 2050. ${ }^{258}$ The second general goal is to implement measures to strengthen the City's resilience, reducing the social, economic, and environmental vulnerabilities of the population of São Paulo and increasing its adaptive capacity. ${ }^{259}$ Strategies include preserving the Atlantic Forest and generating sustainable wealth and work. ${ }^{260}$

\subsubsection{Energy}

Energy efficiency and sustainability standards, both for new and existing buildings, are recommended by the 2009 Climate Change Law ${ }^{261}$ and by the 2014 Master Plan. ${ }^{262}$ The latter, in particular, sets a series of detailed guidelines pertaining to energy production and consumption in the building sector, with a strong emphasis on the adoption of socio-environmental technologies, ${ }^{263}$ sustainable construction methods, ${ }^{264}$ renewables, and energy co-generation, ${ }^{265}$ including in social housing and slum-upgrading projects. ${ }^{266}$ However, the City

256 Gabriela Marques Di Giulio et al., 'Correction to: Bridging the Gap Between Will and Action on Climate Change Adaptation in Large Cities in Brazil', 19(8) Regional Environmental Change 2503 (2019).

T. T. P. Cortese, 'The Leading Role of Local Authorities in Achieving a Sustainable City (5th Academic International Workshop Advances in Cleaner Production)', 22-25 May 2015, <www.advancesincleanerproduction.net/fifth/files/sessoes/6A/3/cortese_ttp_ abstract.pdf $>$.

258 PlanClimaSP, supra note $247,16$.

259 Ibid.

26 o Ibid.

261 Supra note 255, art. 7.III.

$262 \quad 2014$ Master Plan, supra note 251, art. 7.XI.

263 Ibid., art. 19.II.

264 Ibid., art. 194.XIX.

265 Ibid., art. 119.I.

266 Ibid., art. 292.XIV. 
lost the opportunity to implement these guidelines upon approval of the new Building Code in 2017. Due to considerable resistance from construction-licensing officials and developers, no significant adaptation or mitigation measures were incorporated into the Building Code. The 2020 Climate Action Plan may lead to a revision of the 2017 Building Code, ${ }^{267}$ as several measures pertaining to energy efficiency and consumption in buildings are contemplated in it. Again, political opposition may derail attempts to alter the Building Code, demanding strong political commitment and skilful negotiation by the City's administration.

In terms of mitigation, the 2014 Master Plan aims to maximize the application, efficiency, and effectiveness of urban planning tools for climate change mitigation; to increase renewable energy sources and sustainable construction; and to reduce energy consumption and waste. ${ }^{268}$ Mitigation targets, all highly dependent on national regulations and provisions on the matter, are: to insert energy-efficiency criteria into the Building Code by 2025; to expand the share of renewable PV distributed generation to $3.5 \%$ in residential buildings and $6.5 \%$ in commercial buildings by 2030, further expanding these targets to $16 \%$ and $24 \%$, respectively, by 2050 ; and to expand energy-efficiency renovations and improvements in the City's entire building portfolio by 2030. ${ }^{269} \mathrm{In}$ terms of adaptation, the City aims, among other things, to promote improved ventilation and natural lighting patterns in affordable housing. ${ }^{270}$

\subsubsection{Water}

The 2009 Climate Change Law highlights two key lines of action regarding climate adaptation and water in the building sector. First, the preservation of permeable areas in the City, ${ }^{271}$ in order to absorb water, reduce urban heat zones, improve quality of life, and preserve the landscape. Second, the re-qualification of informal settlements, in order to provide habitable conditions for the residents and to avoid or minimize risks arising from extreme climate events, such as landslides and floods. ${ }^{272}$ Both lines of action are contemplated in the 2014 Master Plan, ${ }^{273}$ which declares adaptation a priority. ${ }^{274}$

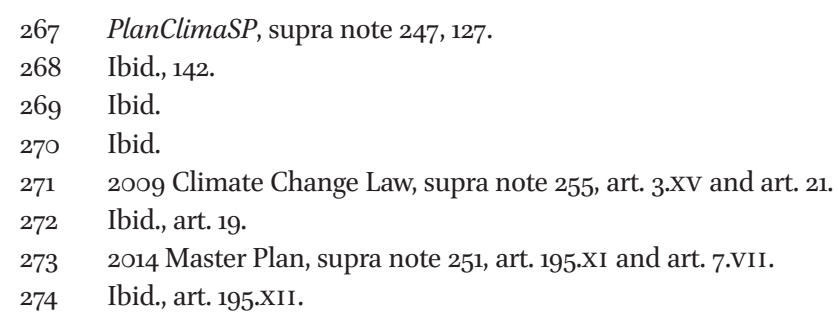


The 2016 Zoning Law has introduced an innovative urban-planning tool, the environmental quota, ${ }^{275}$ a land-use parameter that integrates soil permeability with storm-water retention and vegetation cover in the lot. ${ }^{276}$ In addition, in 2019, the City approved a Municipal Policy on Water Security and Management ${ }^{277}$ to coordinate all implicated policies, programs, and projects pertaining to the protection, conservation, recovery, management, provision of relevant public services, and other actions of local interest concerning water within its jurisdiction. However, the competent municipal agency to implement this policy has not yet been created.

Despite a variety of legal provisions, adaptation has not been effectively prioritized by the City's administration. Informal settlements at the margins of the City's rivers, streams, and water dams, present serious challenges in terms of housing, sanitation, and disaster-risk reduction. ${ }^{278}$ The progressive expansion of squatter settlements in the City's wetlands increasingly endangers water security. 279 Construction incentives granted by the 2014 Master Plan $^{280}$ and the 2016 Zoning Law ${ }^{281}$ to favour densification in the proximity of the main transportation axes have increased soil impermeability in the City's central areas, possibly aggravating existing heat islands and enhancing flood risks. A report by the Municipality in $2018^{282}$ indicated a substantial increase in the construction of new developments in the city centre. The Brazilian Annual

2752016 Zoning Law, supra note 252, arts 74-6.

276 See also Paulo Mantey Domingues Caetano, Hélia Maria Santa Bárbara Pereira, Lara Cavalcanti Ribeiro Figueiredo, Patrícia Marra Sepe, and Leandro Luiz Giatti, "The City of São Paulo's Environmental Quota: A Policy to Embrace Urban Environmental Services and Green Infrastructure Inequalities in the Global South', 3 Frontiers in Sustainable Cities $5^{\circ}$ (2021).

277 Prefeitura de São Paulo, 'Lei no 17.104, de 30 de maio de 2019', 2019, <https://legislacao. prefeitura.sp.gov.br/leis/lei-17104-de-3o-de-maio-de-2019> (Municipality of São Paulo, Law 17.104 of 3o May 2019).

278 Maria de Assunção Ribeiro Franco, Paulo Renato Mesquita Pellegrino, and Taícia Helena Negrin Marques, 'São Paulo on Climate Change: Studies and Proposals for Urban Resilience', 8(1) Revista LABVERDE 120 (2017), 132.

279 Laís Fajersztajn and Paulo Saldiva, 'Impactos da Crise Hídrica em São Paulo na Saúde', in Livro Branco da Água: A Crise Hídrica Na Região Metropolitana de São Paulo Em 2013-2015: Origens, Impactos e Soluções, edited by Marcos Silveira Buckeridge and Wagner Costa Ribeiro (São Paulo: Instituto de Estudos Avançados, 2018), 89-100.

280 Supra note 251 , arts $75^{-84}$.

281 Supra note 252, art. 2.I and art. 7 .

282 Prefeitura de São Paulo, 'Informes Urbanos Vol. 33', May 2018, <www.prefeitura.sp.gov.br/ cidade/secretarias/upload/Informes_Urbanos/IU_Centro_2018_rev-min.pdf>. 
Land Use and Land Cover Mapping Project ${ }^{283}$ has registered an increase of 838 hectares in the City's urbanized area between the years of 2015 and 2020.

However, it is doubtful whether the 2020 Climate Action Plan will be able to boost local adaptation action in order to meet the City's pressing needs for water in the building sector. The adaptation goals are too broadly stated, and the plan fails to set minimally clear, objective targets. For instance, the plan aims to increase the supply of affordable housing by 2050, but it does not specify what concrete measures will be taken by the City to pursue this objective. The plan does not even indicate an estimate of units that the City intends to build in the near future, let alone through to 205 .

Other adaptation objectives ${ }^{284}$ and corresponding targets ${ }^{285}$ are equally vague and insubstantial. To minimize flooding and to decrease vulnerability in areas prone to flooding, the Climate Action Plan pledges to include flood-zone analysis in the zoning law by 2025 and to increase and strengthen flood-prevention programs by 2030 . To decrease the vulnerability of public and private real-estate projects and to protect the population against extreme climate events, the chosen targets for 2025 are to improve environmental-quality assessment indices and to include climate mitigation and adaptation action in environmental licensing requirements; and, by 2030, to increase and guarantee the monitoring of climate-related urban-planning tools. To provide and guarantee financial resources for adaptation, the chosen target is limited to establishing criteria for the application of municipal funds in climate change action by $203 \mathrm{O}$. Finally, to encourage responsible water consumption, the Plan pledges to implement a Drought Contingency Plan by 203 .

\subsubsection{Green Infrastructure}

The 2009 Climate Change Law contemplates two key adaptation actions on green infrastructure: first, the recovery of permanent preservation areas, especially floodplains, to avoid or minimize the impact of extreme climate events; ${ }^{286}$ and second, the afforestation of public roads and the renovation of public sidewalks to expand permeable areas and minimize flood risks. ${ }^{287}$ The 2014 Master Plan pledges to invest in macro-drainage measures combining grey, blue, and green infrastructure; ${ }^{288}$ and to enhance the urbanization of

283 мАРвіомAS, 'Brasil, v.6.o', no date', <https://mapbiomas.org/en?cama_set_language=en >.

284 PlanClimaSP, supra note $247,184$.

285 Ibid., 185 .

2862009 Climate Change Law, supra note 255, art. 20.

287 Ibid., art. 3.XV and art. 23.

2882014 Master Plan, supra note 251, art. 218. 
informal settlements, ${ }^{289}$ strengthen the implementation of contiguous parks along the bottom of valleys, ${ }^{290}$ and the afforestation of public roads and sidewalks. The 2019 Municipal Sanitation Plan ${ }^{291}$ acknowledges the implementation of green infrastructure as a key strategy to control water pollution. An Urban Afforestation Plan, ${ }^{292}$ approved in 2020, is currently being implemented.

The 2020 Climate Action Plan contemplates the increase of rainwater infiltration and green areas as a key adaptation objective. ${ }^{293}$ It also pledges to expand the permeability of public spaces; to identify potential and priority public places suitable for nature-based projects; and to incorporate such practices in public drainage works by $2025 .{ }^{294}$ As previously noted, adaptation targets are excessively broad and open. Also, the Plan does not take into consideration potential conflicts between the urbanization of informal settlements and green infrastructure, disregarding the fact that these two adaptation actions often compete for the same spaces in the City.

Despite legal provisions encouraging the implementation of nature-based projects in the City, blue- and green-infrastructure projects are costly and, therefore, suffer from severe budgetary constraints. Also, urban-planning objectives regarding densification, which provide the City with financial resources through the payment of development rights, clearly conflict with the expansion of green and permeable areas. Due to economic pressures, densification has been prioritized. A lack of political will and an influence of dominant economic interests may continue to jeopardize the implementation of blue- and green-infrastructure projects in the City.

A summary of key information presented in this section is given in Tables 1 and 2.

\footnotetext{
289 Ibid., art. 7.VII.

290 Ibid., art. 272.I.

291 Prefeitura de São Paulo, 'Plano Municipal de Saneamento Básico', 2019, <https:// gestaourbana.prefeitura.sp.gov.br/wp-content/uploads/2019/05/PMSB_Caderno_ Completo_-final-para-impressa\%CC\%83o.pdf>.

292 Prefeitura De São Paulo, 'Plano Municipal de Arborização Urbana', 2020, <www.prefeitura. sp.gov.br/cidade/secretarias/upload/meio_ambiente/arquivos/pmau/PMAU_texto_final. pdf $>$.

293 PlanClimaSP, supra note $247,184$.

294 Ibid., 185.
} 
TABLE 1 Overview of data relating to greenhouse gas emissions in the three cities

\begin{tabular}{|c|c|c|c|}
\hline & Cape Town & Hamburg & São Paulo \\
\hline Inhabitants & 4 million & 1.6 million & 12.1 million \\
\hline $\begin{array}{l}\text { Inhabitants } \\
\text { metropoli- } \\
\text { tan area }\end{array}$ & 4 million & 5 million & 21.5 million \\
\hline \multirow{8}{*}{$\begin{array}{l}\text { Pledges at } \\
\text { NAzCA } \\
\text { (only mit- } \\
\text { igation, no } \\
\text { adaptation) }\end{array}$} & Joining of the & Climate neutral & Reduce total city- \\
\hline & Climate Ambition & by $205^{\circ}$ (at least & wide emissions \\
\hline & Alliance to achieve & $95 \%$ reduction of & by $30 \%$ by 2020 \\
\hline & net-zero $\mathrm{CO}_{2}$ & $\mathrm{CO}_{2}$ emissions by & compared to 2010 \\
\hline & $\begin{array}{l}\text { emissions by } 205^{\circ} \text {; } \\
\text { further pledges } \\
\text { in the fields of }\end{array}$ & $\begin{array}{l}2050 \text { compared to } \\
199 \text { o levels); joining } \\
\text { of the Climate }\end{array}$ & $\begin{array}{l}\text { levels }{ }^{297} \text { (however, } \\
\text { total emissions have } \\
\text { increased from }\end{array}$ \\
\hline & & Ambition Alliance & 13.7 to $15.4 \mathrm{Mt} \mathrm{CO}_{2}$ \\
\hline & buildings, low-car- & to achieve net-zero & eq. between 2010 and \\
\hline & $\begin{array}{l}\text { bon vehicles, and } \\
\text { divestment }^{295}\end{array}$ & $\begin{array}{l}\mathrm{CO}_{2} \text { emissions by } \\
2 \mathrm{O}^{\circ} \mathrm{O}^{296}\end{array}$ & $\left.2017^{298}\right)$ \\
\hline \multirow{2}{*}{$\begin{array}{l}\text { Per-capita } \\
\text { emissions }\end{array}$} & $5.6 \mathrm{t} \mathrm{CO}_{2}(2 \mathrm{O} 17)$ & slightly above & $1.4 \mathrm{t} \mathrm{CO}_{2}(2 \mathrm{O} 6)^{299}$ \\
\hline & & $8 \mathrm{t} \mathrm{CO}_{2}(2 \mathrm{O} 19)$ & \\
\hline \multirow{9}{*}{$\begin{array}{l}\text { Emission- } \\
\text { reduction } \\
\text { targets } \\
2030 / 205^{0}\end{array}$} & $\mathrm{CO}_{2}$ emissions & $55 \% \mathrm{CO}_{2}$ emission & $50 \%$ emission \\
\hline & to peak by 2035 & reduction by 2030 & reduction by 2030 \\
\hline & climate neutrality & compared to 1990 & compared to 2017 \\
\hline & by $205^{\circ}$ & climate neutrality & levels, with the goal \\
\hline & & $\left(=95 \% \mathrm{CO}_{2}\right.$ emis- & to achieve zero \\
\hline & & sion reduction) by & emissions in $205^{\circ}$ \\
\hline & & 2050, compared & \\
\hline & & to 1990, measured & \\
\hline & & $\begin{array}{l}\text { in final energy } \\
\text { consumption }\end{array}$ & \\
\hline
\end{tabular}

295 NAZCA, 'Cape Town', no date, <https://climateaction.unfccc.int/views/Actors/Cities/ GCAP $3539>$.

296 NAZCA, 'Hamburg', no date, <https://climateaction.unfccc.int/views/Actors/Cities/ GCAP6oo1>.

297 NAZCA,' São Paulo', no date, <https://climateaction.unfccc.int/views/Actors/Cities/ GCAP4158>.

298 PlanClimaSP, supra note $247,99$.

299 Ibid., 123. 
TABLE 1 Overview of data relating to greenhouse gas emissions in the three cities (cont.)

\begin{tabular}{|c|c|c|c|}
\hline & Cape Town & Hamburg & São Paulo \\
\hline $\begin{array}{l}\text { Emission- } \\
\text { reduction } \\
\text { targets } \\
2030 / 205^{\circ} \\
\text { per capita }\end{array}$ & None & $\begin{array}{l}6 \mathrm{t} / \mathrm{y} \text { by } 2030 \text { and } \\
2 \mathrm{t} / \mathrm{y} \text { by } 2050 \text { (only } \\
\mathrm{CO}_{2} \text { ) }\end{array}$ & None \\
\hline $\begin{array}{l}\text { Sectoral } \\
\text { emissions }\end{array}$ & $\begin{array}{l}\text { Transport } 33 \% \text {, } \\
\text { commercial } 26 \% \text {, } \\
\text { residential } 22 \% \text {, } \\
\text { industrial } 11 \% \text {, } \\
\text { government } 2 \% \text {, } \\
\text { agriculture } 1 \% \text {; } \\
\text { total: } 19 \mathrm{Mt} \mathrm{CO}_{2} \text { eq. } \\
\text { in } 2012^{300}\end{array}$ & 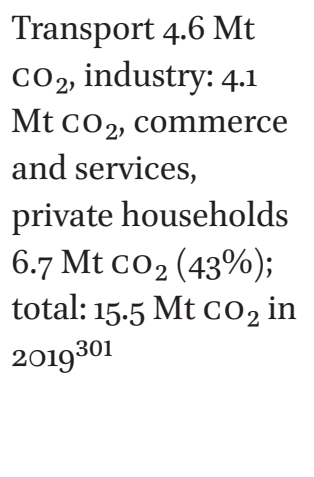 & $\begin{array}{l}\text { Transport 9.6 Mt } \\
\mathrm{CO}_{2} \text { eq., stationary } \\
\text { energy } 4.6 \mathrm{Mt} \mathrm{CO}_{2} \\
\text { eq. (residential } 2.1 \mathrm{Mt} \\
\mathrm{CO}_{2} \text { eq., commercial } \\
1.3 \mathrm{Mt} \mathrm{CO}_{2} \text { eq., indus- } \\
\text { trial o.9 } \mathrm{Mt} \mathrm{\textrm {CO } _ { 2 }} \text { eq.), } \\
\text { waste } 1.2 \mathrm{Mt} \mathrm{CO}_{2} \text { eq.; } \\
\text { total: } 15.4 \mathrm{Mt} \mathrm{CO}_{2} \text { eq. } \\
\text { in } 2017^{302}\end{array}$ \\
\hline $\begin{array}{l}\text { Adaptation } \\
\text { targets, } \\
\text { guidelines, } \\
\text { aspirations }\end{array}$ & $\begin{array}{l}\text { No quantifiable } \\
\text { indicators so far; } \\
\text { very broad } \\
\text { 'strengthen resil- } \\
\text { ience and reduce } \\
\text { vulnerability'; } \\
\text { enhance 'ability to } \\
\text { prepare for, adapt } \\
\text { to and recover from } \\
\text { shocks and chronic } \\
\text { stresses' }\end{array}$ & $\begin{array}{l}\text { 'Climate- } \\
\text { resilient city'; } \\
\text { Transformation } \\
\text { Pathway Climate } \\
\text { Adaptation; no } \\
\text { quantified indica- } \\
\text { tors so far }\end{array}$ & $\begin{array}{l}\text { Targets are broad } \\
\text { and open ('adapt- } \\
\text { ing today's city for } \\
\text { tomorrow', 'strength- } \\
\text { ening urban resil- } \\
\text { ience', 'enhancing } \\
\text { adaptive capacity'); } \\
\text { some lack quantified } \\
\text { indicators }\end{array}$ \\
\hline
\end{tabular}

$300 \quad$ City of Cape Town, Climate Change Policy, supra note 184, 13.

301 Hamburg, supra note 223. The accounting in Hamburg follows the methodology of German states. It is energy-based only. For detailed information, see Länderarbeitskreis Energiebilanzen, ' $\mathrm{CO}_{2}$-Bilanzen', no date, <http://www.lak-energiebilanzen.de/ co2-bilanzen/>.

302 PlanClimaSP, supra note $247,104$. 


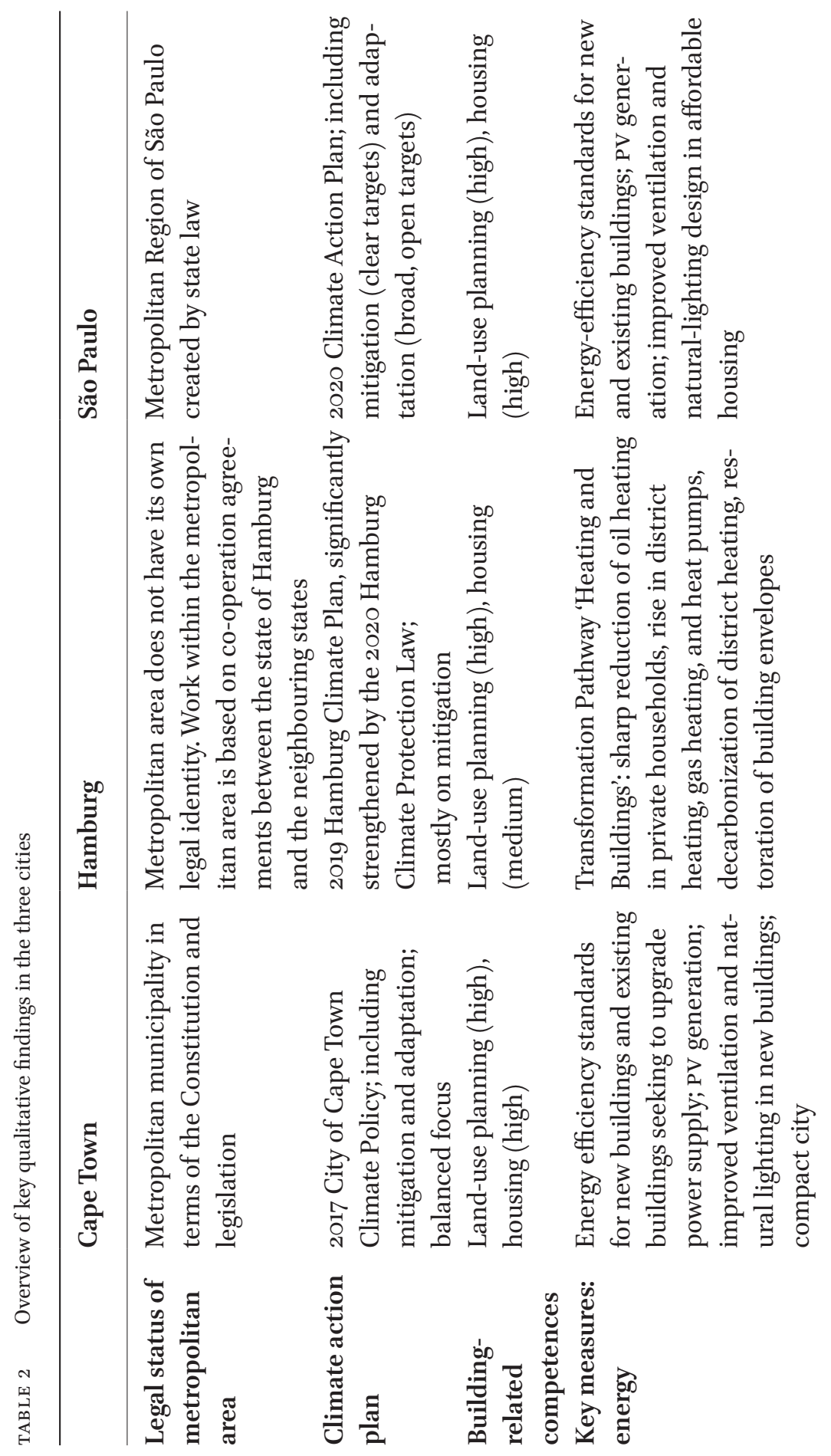



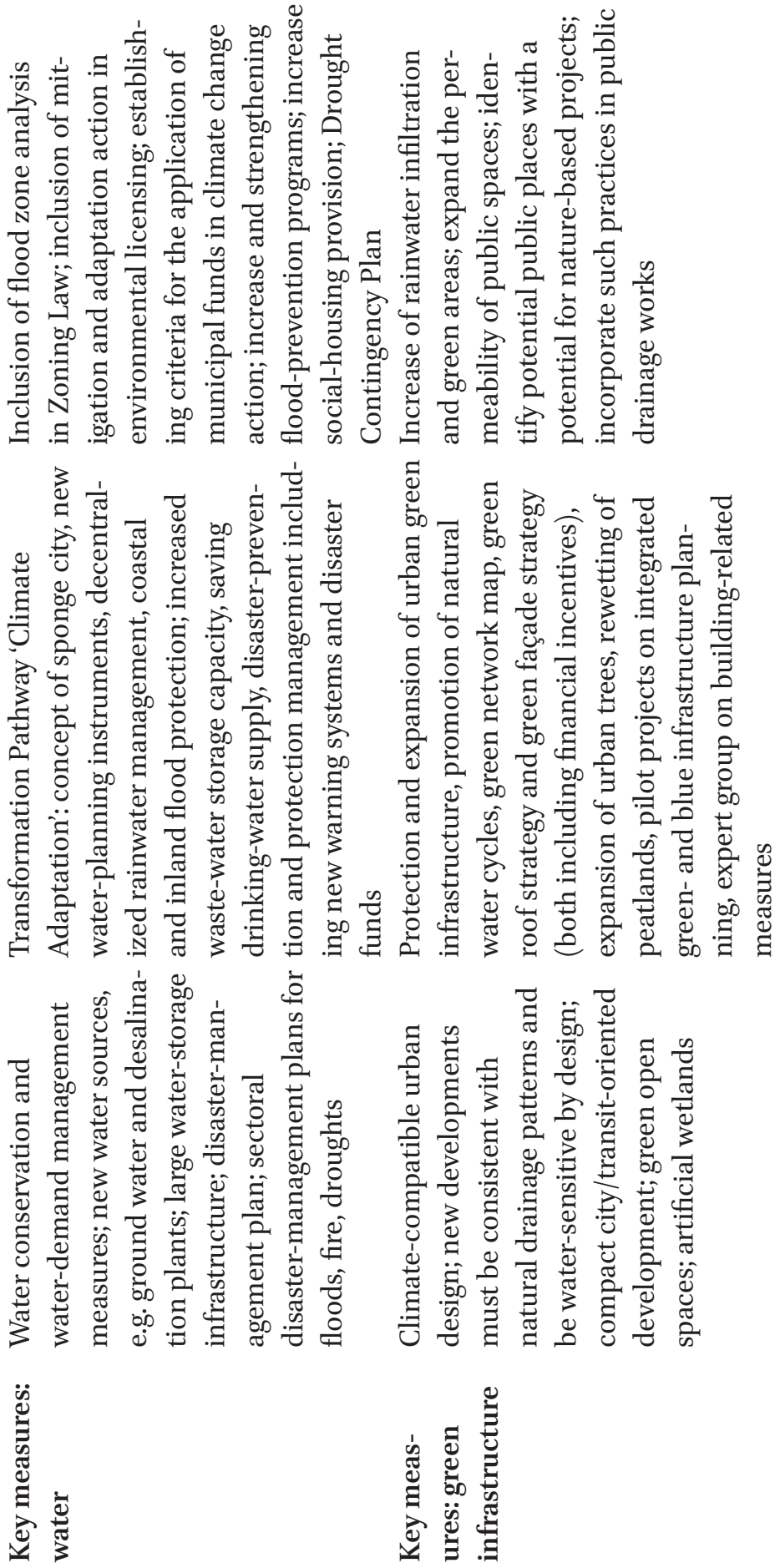


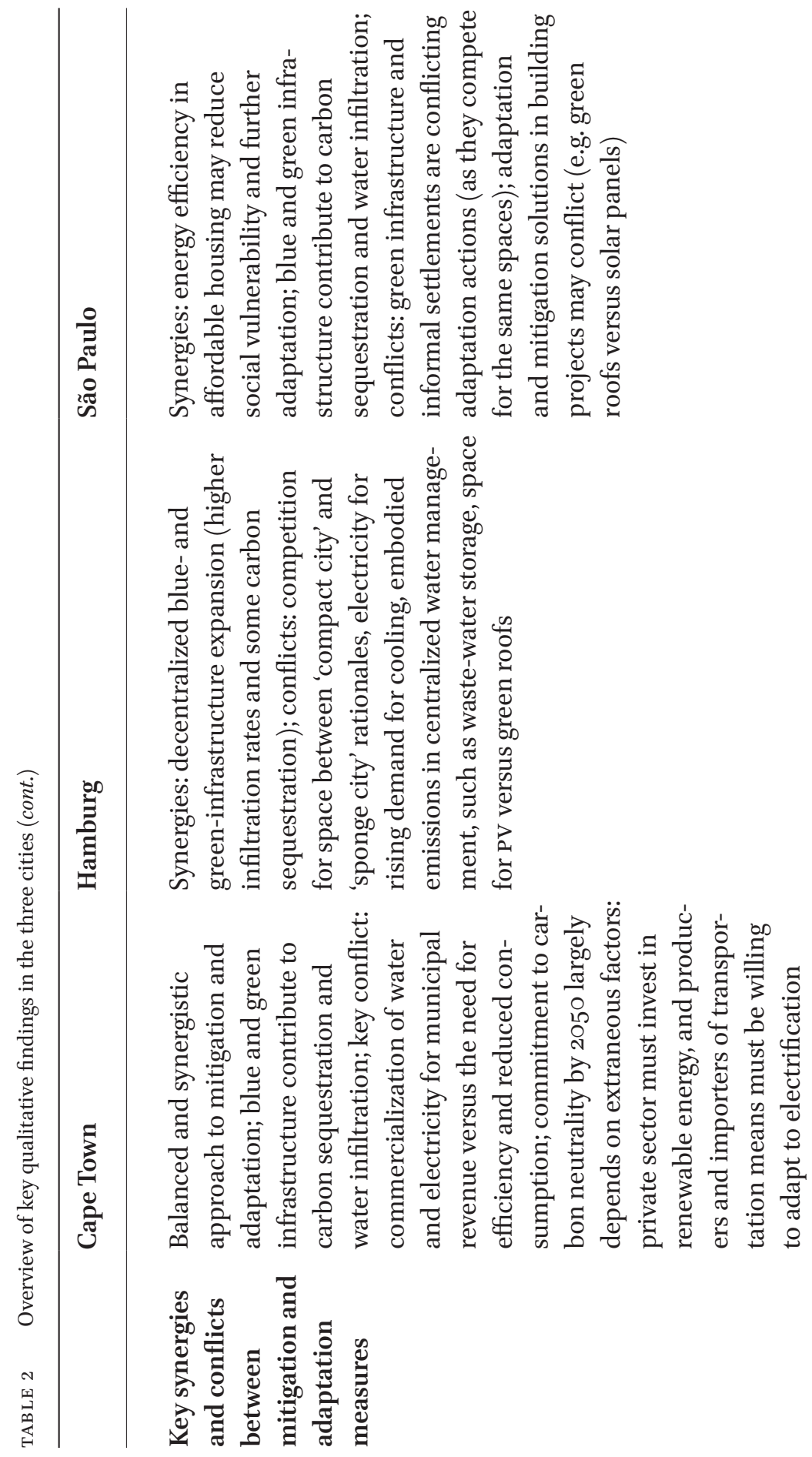




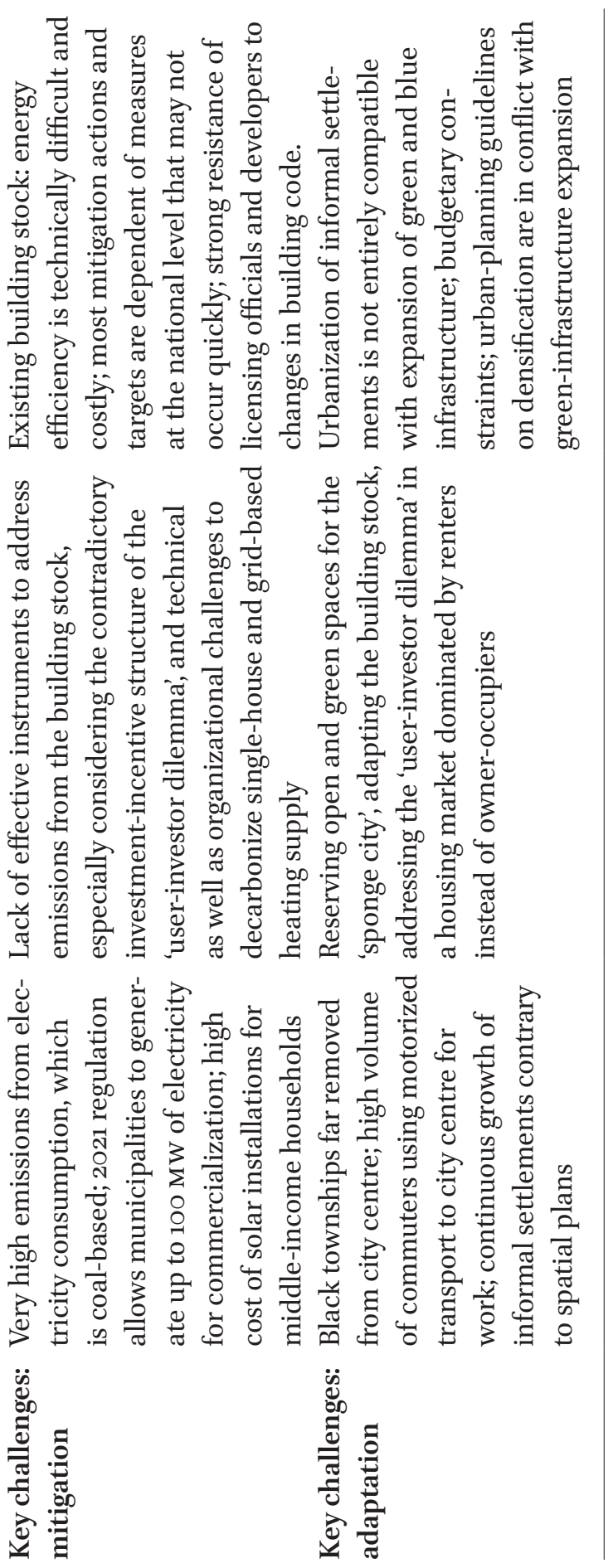


The main challenge that usually confronts legal comparatists is how to determine the scope of their comparative analysis. ${ }^{303}$ This is because there are typically elements in each legal system that are roughly the functional equivalents of elements in other legal systems. ${ }^{304}$ To circumvent the temptation of 'comparing apples and oranges', ${ }^{305}$ we begin by first identifying a common point of departure for the comparison, the ideal of addressing climate change mitigation and adaptation in the building sector (tertium comparationis) and then ask how the legal systems in our three selected countries enable municipalities to respond to it. Second, we investigate how similarities and differences in each legal system under investigation enable our selected cities to respond to the ideal. The third level of comparative analysis looks at how the three cities have responded to their legal climate mandates through the building sector. This approach ensures that there are three layers to our comparative analysis: international commitments, national standards, and city-level action.

From an international 'soft law' perspective, cities have a political mandate to contribute toward climate change mitigation and adaptation in a diverse range of sectors. In this regard, NAZCA is a voluntary global platform that some cities have joined, including our three cities. Brazil, Germany, and South Africa submitted their respective NDCs in line with their obligations to meet the goals of the Paris Agreement. The 2021 updated NDC for South Africa recognizes the importance of the building sector and the role of cities for climate change adaptation. With regard to Brazil, while the NDC of 2015 highlighted the role of cities in adaptation, the updated NDC from 2020 does not mention adaptation at all. Neither the South African nor the Brazilian updated NDCs mention the contribution of municipalities to climate change mitigation. Germany is under a joint NDC as part of the European Union; this NDC focuses on mitigation targets and does not refer to the building sector or to the role of cities.

The second area of comparison lies in the scope of legal powers in the building sector enjoyed by cities in the three jurisdictions, as they relate to climate change action. This is important because the level to which cities can contribute towards climate change mitigation and adaptation in the building sector is mostly informed by the nature of their powers and functions over the building sector as defined in national constitutions, statutes, and policies. The discussion of the constitutional frameworks in Section 3.1 showed that all three

\footnotetext{
303 See Reitz, supra note $23,620$.

304 Ibid., 620-1.

305 Ibid., 621.
} 
cities operate within federal systems of government that allow higher levels of government to regulate the exercise of their powers and functions through legislation. Hamburg is part of a two-level federal system of government. On the other hand, Cape Town and São Paulo operate in a three-level federal system. While municipalities in Brazil and South Africa are themselves a level of government, municipalities in Germany are not a level of government but are the regional authorities of federal states. Despite this difference, the legislative, administrative, and fiscal powers of municipalities in all three countries are constitutionally protected.

There is no enforceable duty on municipalities in Brazil and Germany to address climate change, in contrast with municipalities in South Africa, which are under a constitutionally enforceable duty to contribute towards climate change mitigation and adaptation. However, municipalities in the former two countries have powers to respond to climate change. This suggests that municipalities in Brazil and Germany largely depend on local political will for municipal climate-related action. Nevertheless, the functional areas of competence of municipalities in all three countries in terms of national constitutions and legislation put them in a position where they can contribute towards mitigation and adaptation in the building sector, as they are responsible for urban and land-use planning, land-use regulations, building regulations, solid-waste disposal, storm-water management, and the supply of water and energy. They are required to contribute towards disaster-risk reduction and disaster management. Therefore, municipalities in the three jurisdictions hold significant powers in the building sector and in the related sub-sectors of energy, water, and green infrastructure, which can be used to promote mitigation and adaptation in their jurisdictions.

The discussion of national legal frameworks showed that the three countries have specific legislation in the fields of urban planning, building regulations, green infrastructure, storm-water management, disaster management, provision of water services, and electricity generation and distribution. The comparative analysis shows that these statutes give municipalities significant powers over land-use planning and approvals, the regulation of buildings, building-related drinking-water demand and supply, waste-water management, flood prevention, and green infrastructure.

On the other hand, it also shows municipalities' limited influence on electricity generation and supply in all three jurisdictions. Municipal climate policies, plans, strategies, and local laws must be aligned with the dictates of national statutes. These generally set out principles, minimum standards, and tools that should be implemented by municipalities in the building sector. Regarding areas such as drinking-water supply, waste-water treatment, 
and energy-efficiency measures, municipalities with available resources can go beyond prescribed minimum standards. In areas of land-use planning and green-infrastructure development, municipalities have greater autonomy.

For Germany, there is an additional layer of EU regulation in the areas of energy efficiency, drinking water, waste water, and flood prevention which municipalities must comply with. The German Federal Building Code requires municipalities to use land-use plans to contribute to climate mitigation and adaptation. They can also employ urban-development contracts and (re) development by-laws for this purpose. In South Africa, regulations adopted under the NBRBs Act of 1977 introduced energy-efficiency measures for buildings that promote climate mitigation and adaptation. The NBRBS Act is implemented by municipalities. In Brazil, urban planning and building codes are essentially within the competence of municipalities. In addition, the analysis of state law (in Section 4) showed that, while provinces have very limited building-related influence over municipalities in South Africa, in Germany and Brazil states have a significant scope of action to shape municipal climate mitigation and adaptation efforts related to buildings. This means that states can significantly increase the number of regulations which municipalities must comply with in Germany and Brazil.

As is evident from the case-study section and Table 2, all three cities have plans and policies, as well as by-laws in some instances, which directly address climate mitigation and adaptation in the building sector. In addition, the cities of Cape Town, Hamburg, and São Paulo aspire for climate neutrality by 2050 . However, even if there were political will, it is doubtful whether there exist sufficient resources and even legal scope of competence to reach those targets by mere local action. Multilevel governance support is imperative to achieve such goals. In comparison to mitigation, adaptation targets in all three cities are only vaguely formulated and emphasize the need to promote resilience, adaptive capacity, and reduce vulnerabilities.

The comparative analysis has also revealed synergies and conflicts between some mitigation and adaptation measures in the three cities. There is synergy in blue-and green-infrastructure development as it has the potential to contribute toward carbon sequestration and water infiltration. However, there is an inherent tension in the competition for space between the 'compact city' and 'sponge city' rationales. ${ }^{306}$ This competition, if not well managed, can lead to unintended consequences, such as increased flooding in compact cities. Adaptation and mitigation solutions in building projects may conflict in practice, such as the requirement for solar panels and green roofs in Hamburg and São Paulo. Our

306 See supra note 244 for a brief explanation and further references. 
analysis also shows what is unique about the three cities. For example, although Cape Town appears to have adopted a balanced and synergetic approach to mitigation and adaptation, there is an inherent conflict in its ambition to achieve emission neutrality in 2050 and its heavy reliance on coal-powered electricity to sustain its fast-growing economy. In addition, the sale of electricity, just like water, is a major source of revenue for the City. Furthermore, the regulatory framework for climate mitigation and adaptation in Cape Town is extremely fragmented. In Hamburg, competition for space for PV and green roofs, additional electricity consumption for rising cooling demand as well as embodied emissions in new grey infrastructure for climate adaptation present potential conflicts. With regard to São Paulo, there are key conflicts between green infrastructure and informal settlements as they compete for space.

Two main challenges face the three municipalities. First, they have very limited power over commercialized electricity production. This affects their ability to significantly limit $\mathrm{CO}_{2}$ emissions in this sector. Second, despite their fiscal powers, revenue generation is inadequate to meet their needs for effective decarbonization and adaptation.

\section{$7 \quad$ Conclusion}

The aim of this article has been to contribute to the growing body of urban climate-governance research from a comparative legal perspective. We have analysed the climate mitigation and adaptation efforts in the building sector of three cities, through the case studies of Cape Town, Hamburg, and São Paulo. Our methodological framework looked into the national-, state-, and local-level laws and policies with a focus on building-related energy, water, and green infrastructure.

We conclude with the following key findings:

(a) with regard to the national level, the constitutions, legislation, and policies of the federal states of Brazil, Germany, and South Africa equip municipalities with powers and instruments required to design and implement climate mitigation and adaptation measures in the building sector;

(b) only South Africa has a clear constitutionally enforceable duty on municipalities to contribute towards climate mitigation and adaptation;

(c) whereas South Africa does not have national legislation on climate change, Brazil and Germany have national climate laws. However, only the Brazilian climate law explicitly addresses the municipal level. Due to constitutional constraints, the German national climate law may 
not refer new tasks to municipalities; this law is also for now limited to mitigation;

(d) in all three jurisdictions, municipalities cannot generate enough revenue for effective climate action, although their fiscal powers are legally guaranteed; current revenue generation is often at odds with climate targets;

(e) national legislation as well as constitutions refer a rather large scope of action to municipalities in the fields of building-related land-use planning, water, and green-infrastructure development; however, in the energy sector, decarbonization of electricity generation is mainly in the hands of national governments; and, in the case of Germany, also guided by EU legislation;

(f) in Brazil and Germany, state-level legislation and policies impose an extra layer of relevant responsibilities and instruments on municipalities;

(g) all three cities have policies, plans, and strategies directed to promoting climate mitigation and adaptation, and are committed to attain climate neutrality by 2050 . Despite this, none of the countries oblige municipalities to reach defined emission-reduction targets. Success largely depends on local political will and financial resources. ${ }^{307}$ All three cities define local mitigation targets and measures in greater detail than adaptation targets and measures;

(h) it is questionable whether the three cities will be able to reach the ambitious mitigation targets in the building sector, considering their limited financial capacity and their almost non-existent power over electricity generation.

Certain ideas for improvement follow from these findings. With regard to strengthening the role of cities in climate mitigation and adaptation efforts at the international plane, policymakers at the international level may need to consider widening the scope of NAZCA to cities' adaptation targets and measures and address the challenge of funding in discussing options to financially support ambitious local mitigation and adaptation efforts. National policymakers may consider including adaptation targets in future NDCs and also explicitly mention the role of cities in order to strengthen the political mandate for local mitigation and adaptation. At the national level, considering the urgency of effective climate mitigation and adaptation, an enforceable mandate for local authorities in Brazil and Germany may be worth considering.

307 For an assessment of adaptation planning in large cities which also identifies limited funding as a crucial constraint next to a range of other factors, see Marta Olazabal and Maria Ruiz De Gopegui, 'Adaptation Planning in Large Cities is Unlikely to be Effective', 206 Landscape and Urban Planning 1 (2021). 
Whereas in Brazil there is constitutional scope for action on such a national obligation on municipal climate action, ${ }^{308}$ in Germany such a change requires a change in constitutional law. ${ }^{309}$ Where resources permit, the three municipalities could explore innovative ways to use their autonomy in land-use planning and green-infrastructure development more than they currently do, to go beyond prescribed minimum standards in building-related energy and water infrastructure to strengthen their contribution to climate mitigation and adaptation. National and state governments could strengthen fiscal allocations in support of ambitious and effective municipal mitigation and adaptation efforts in order to incentivize and enable local climate action. In all three cities planners and policymakers need to strike a fine balance between the rationales of compact and sponge cities. To better manage the tension born of these competing rationales, the three cities could strengthen integrated planning in terms of substantive design of instruments as well as institutional settings. More precisely, all three cities could enhance their efforts to overcome siloed decision-making and implementation, thereby creating synergies between climate mitigation and adaptation efforts. ${ }^{310}$

\section{Acknowledgment}

The authors wish to thank the Volkswagen Foundation for funding the cost of making this article open access. The funding was provided through the Freigeist Fellowship, “Urban Footprints”, to Cathrin Zengerling.

\footnotetext{
308 National laws can either deny access to national funding lines for municipalities that fail to approve local policies or plans in due time or render mayors personally responsible for such failure. Similar measures have been imposed in Brazil by the National Statute of the City and by the National Sanitation Policy, with no adverse rulings by courts.

309 See discussion above in Section 3.1.2.

310 For a study of options and benefits of integrated mitigation and adaptation planning based on a large sample of cities, see Jo-Ting Huang-Lachmann and Edeltraud Guenther, 'From Dichotomy to an Integrated Approach: Cities' Benefits of Integrating Climate Change Adaptation and Mitigation', 12(18) Sustainability 1 (2020). See also Stelios Grafakos, Kate Trigg, Mia Landauer, Lorenzo Chelleri, and Shobhakar Dhakal, 'Analytical Framework to Evaluate the Level of Integration of Climate Adaptation and Mitigation in Cities', 154(1) Climatic Change 87 (2019).
} 